\title{
Achieving glycemic control in elderly patients with type 2 diabetes: a critical comparison of current options
}

This article was published in the following Dove Press journal:

Clinical Interventions in Aging

I8 November 2014

Number of times this article has been viewed

\author{
Ye-Fong Du' \\ Horng-Yih Ou' \\ Elizabeth A Beverly ${ }^{2}$ \\ Ching-Ju Chiu ${ }^{3}$ \\ 'Division of Endocrinology and \\ Metabolism, Department of Internal \\ Medicine, National Cheng Kung \\ University Hospital, Tainan, Taiwan; \\ ${ }^{2}$ Department of Social Medicine, \\ Ohio University Heritage College \\ of Osteopathic Medicine, Athens, \\ $\mathrm{OH}$, USA; ${ }^{3}$ Institute of Gerontology, \\ College of Medicine, National Cheng \\ Kung University, Tainan, Taiwan
}

\begin{abstract}
The prevalence of type 2 diabetes mellitus (T2DM) is increasing in the elderly. Because of the unique characteristics of elderly people with T2DM, therapeutic strategy and focus should be tailored to suit this population. This article reviews the guidelines and studies related to older people with T2DM worldwide. A few important themes are generalized: 1) the functional and cognitive status is critical for older people with T2DM considering their life expectancy compared to younger counterparts; 2) both severe hypoglycemia and persistent hyperglycemia are deleterious to older adults with T2DM, and both conditions should be avoided when determining therapeutic goals; 3 ) recently developed guidelines emphasize the avoidance of hypoglycemic episodes in older people, even in the absence of symptoms. In addition, we raise the concern of glycemic variability, and discuss the rationale for the selection of current options in managing this patient population.
\end{abstract}

Keywords: glycemic target, glycemic variability, blood glucose, frailty

\section{Introduction}

Diabetes prevalence in older people increases with advancing age. The global prevalence of diabetes in people between the ages of 60 and 79 is $18.6 \%$, which is more than 134.6 million people, and accounts for $35 \%$ of all cases of diabetes in adults. ${ }^{1}$ Peripheral neuropathy, which is highly prevalent in older people with diabetes, increases the risk of falls and fractures, and consequently, of functional impairment. ${ }^{2}$ Diabetes in older people is also associated with dementia and depression. ${ }^{3,4}$ Diabetic patients with depressive symptoms may need more attention in treating their condition, ${ }^{5}$ particularly women. ${ }^{6}$ Age-associated alteration in metabolism and excretion of medication is also a concern in the selection of antidiabetic treatment. ${ }^{7}$ Older people are also at increased risk of undernutrition and skeletal muscle loss, which is generally even more evident with the presence of diabetes. ${ }^{8,9}$ Older people with diabetes are considered at high cardiovascular risk. ${ }^{10}$ Risk of hypoglycemia is also increased due to impaired counterregulatory mechanisms. ${ }^{11}$ These biopsychosocial changes increase the complexity in managing diabetes in older adults. Importantly, much attention has been paid to optimal glycemic control in the elderly in the past few years. Guidelines focusing on the elderly with diabetes were developed all over the world in the past decade with increasing focus on cognition and functional capacity. ${ }^{10,12-18}$ This review of the literature, in addition to summarizing opinions from recently published guidelines and studies, elucidates the pathophysiological characteristics of elderly patients with type 2 diabetes mellitus (T2DM), and discusses the rationale for selection of current options in managing this patient population.
Correspondence: Ching-Ju Chiu Gerontology, College of Medicine, National Cheng Kung University, No I, University Road, Tainan, Taiwan, 7010I

Tel +886 62353535 ext 5739

Fax +88663028175

Email cjchiu@mail.ncku.edu.tw 
Clinical studies included in this article define elderly subgroups chronologically as aged 65 years or more to facilitate the analysis of the data.

\section{Rationale in determining therapeutic goals for older patients}

Heterogeneity of older adults cannot be overemphasized in diabetes care. Some adults were diagnosed with T2DM after age 65 with initial presentation of hyperglycemia crisis and established chronic complications; some were diagnosed from health screening without any complications, and others were diagnosed as young adults or during middle age and sustained till old age with or without microvascular complications. ${ }^{14}$ Guidelines developed in recent years all highlight the need to customize therapeutic goals for various older adults with T2DM (Table 1). ${ }^{10,12,14,19-21}$ Generally, appropriate therapeutic goals for older patients with T2DM should be determined based on comprehensive evaluation of cognition, functional status, comorbidities including cardiovascular risk, and geriatric syndromes. ${ }^{22}$

In the past decade, glycemic control was focused on glycated hemoglobin (A1C) level and postprandial glucose. Strict glycemic level is aimed at the prevention of development and progression of chronic complications of diabetes, such as nephropathy, retinopathy, and neuropathy. However, to achieve cardiovascular benefits, a prolonged period of around 10 years is needed after intensive control for 6-12 years, as revealed in the Diabetes Control and Complications Trial/Epidemiology of Diabetes Interventions and Complications study and the United Kingdom
Prospective Diabetes Study (UKPDS). ${ }^{23,24}$ These cardiovascular benefits were not observed after intensive glycemic control in long-established T2DM patients in the Action to Control Cardiovascular Risk in Diabetes (ACCORD) trial, the Action in Diabetes and Vascular Disease: Preterax and Diamicron Modified Release Controlled Evaluation trial, and the Veterans Affairs Diabetes Trial. ${ }^{25-27}$ For diabetic patients with limited life expectancy, maintaining independent function, preventing frailty, and preserving cognition integrity are far more important than targeting A1C alone. ${ }^{17,28}$ Therefore, it is important to avoid hypoglycemia events and consequent adverse outcomes, such as falls, cognitive decline, autonomic dysfunction, depression, recurrent hypoglycemia, poor compliance, and possible cardiac ischemia or arrhythmia, which may contribute to poor function and poor prognosis. ${ }^{29-31}$ Despite the inconsistent relationship between hypoglycemia and falls or fractures, it is still a concern that recurrent hypoglycemia may put elderly people at higher risk for falls. ${ }^{32-35}$ Further, this risk may be even more detrimental if the elderly patients live alone. Elders residing in long-term care facilities are at significant risk of poor functional status, frailty, and malnutrition. These frail elders may be vulnerable to hypoglycemia and its serious morbid outcomes. ${ }^{36}$ On the other hand, older diabetic patients with low A1C levels may be indicative of reduced food intake and malnutrition rather than good glycemic control. ${ }^{37}$ The ACCORD trial is well known for its premature termination after a median duration of 3.5 years because of higher mortality in the intensive group, targeting $\mathrm{A} 1 \mathrm{C}<6 \%$ (42 $\mathrm{mmol} / \mathrm{mol})$. Based on these findings, recommendations from some guidelines propose

Table I Categories of older people with type 2 diabetes in different guidelines

\begin{tabular}{|c|c|c|c|c|}
\hline Guideline & Year & Category I & Category 2 & Category 3 \\
\hline $\mathrm{CHCF}^{19}$ & 2003 & Relatively healthy & Frail, life expectancy $<5$ years & NA \\
\hline VA/DoD 20 & 2004 & $\begin{array}{l}\text { Life expectancy }>15 \text { years } \\
\text { No or minimal microvascular } \\
\text { complications }\end{array}$ & $\begin{array}{l}\text { Life expectancy } 5-15 \text { years } \\
\text { Moderate microvascular } \\
\text { complications }\end{array}$ & $\begin{array}{l}\text { Life expectancy }<5 \text { years } \\
\text { Advanced microvascular complications, } \\
\text { advanced age, severe comorbidity }\end{array}$ \\
\hline VA/DoD 21 & 2010 & Life expectancy $>10-15$ years & $\begin{array}{l}\text { DM duration }>10 \text { years, } \\
\text { comorbid conditions }\end{array}$ & $\begin{array}{l}\text { Life expectancy }<5 \text { years } \\
\text { Advanced microvascular complications, } \\
\text { advanced age, severe comorbidity }\end{array}$ \\
\hline EDWPOP'2 & 2011 & $\begin{array}{l}\text { Single system involvement } \\
\text { Free of major comorbidities }\end{array}$ & $\begin{array}{l}\text { Frail (dependent, multisystem disease, } \\
\text { dementia, care home residents) }\end{array}$ & NA \\
\hline ADA/AGS 14 & 2012 & $\begin{array}{l}\text { Healthy } \\
\text { (Few coexisting chronic illnesses, } \\
\text { intact cognitive and functional } \\
\text { status) }\end{array}$ & $\begin{array}{l}\text { Complex/intermediate } \\
\text { (Multiple coexisting chronic illnesses } \\
\text { or } \geq 2 \text { IADL impairments or mild } \\
\text { to moderate cognitive impairment) }\end{array}$ & $\begin{array}{l}\text { Very complex/poor health } \\
\text { (Long-term care or end-stage chronic illnesses } \\
\text { or } \geq 2 \text { ADL dependences or moderate } \\
\text { to severe cognitive impairments) }\end{array}$ \\
\hline IDF $^{10}$ & 2013 & Functionally independent & $\begin{array}{l}\text { Functionally dependent } \\
\text { frailty or dementia }\end{array}$ & End-of-life care \\
\hline
\end{tabular}

Abbreviations: ADA, American Diabetes Association; ADL, activity of daily life; AGS, American Geriatric Society; CHCF, California HealthCare Foundation; EDWPOP, European Diabetes Working Party for Older People; IADL, instrumental activity of daily life; IAGG, International Association of Gerontology and Geriatrics; IDF, International Diabetes Federation; VA/DoD, Veterans Affairs/Department of Defense; NA, not applicable; DM, diabetes mellitus. 
Table 2 Glycemic targets according to different categories indicated by guidelines worldwide

\begin{tabular}{|c|c|c|c|c|}
\hline Guideline & Year & Category I & Category 2 & Category 3 \\
\hline $\mathrm{CHCF}^{19}$ & 2003 & $\mathrm{AIC} \leq 7 \%(53.0 \mathrm{mmol} / \mathrm{mol})$ & $\mathrm{AIC}=8 \%(63.9 \mathrm{mmol} / \mathrm{mol})$ & NA \\
\hline $\mathrm{VA} / \mathrm{DoD}^{20}$ & 2004 & AIC $<7 \%(53.0 \mathrm{mmol} / \mathrm{mol})$ & AIC $<8 \%(63.9 \mathrm{mmol} / \mathrm{mol})$ & $\begin{array}{l}\text { AIC }<9 \%(74.9 \mathrm{mmol} / \mathrm{mol}) \\
\text { avoid symptomatic hyperglycemia }\end{array}$ \\
\hline VA/DoD ${ }^{21}$ & 2010 & AIC $<7 \%(53.0 \mathrm{mmol} / \mathrm{mol})$ & AIC $<8 \%(63.9 \mathrm{mmol} / \mathrm{mol})$ & $\begin{array}{l}\mathrm{AIC}=8 \%-9 \% \\
(63.9-74.9 \mathrm{mmol} / \mathrm{mol})\end{array}$ \\
\hline EDWPOP'2 & 2011 & $\begin{array}{l}\text { AIC }=7 \%-7.5 \% \\
(53.0-58.8 \mathrm{mmol} / \mathrm{mol}) \\
\text { FPG }=6.5-7.5 \mathrm{mmol} / \mathrm{L}\end{array}$ & $\begin{array}{l}\text { AIC }=7.6-8.5 \% \\
(59.6-69.4 \mathrm{mmol} / \mathrm{mol}) \\
\text { FPG }=7.6-9.0 \mathrm{mmol} / \mathrm{L}\end{array}$ & NA \\
\hline ADA/AGS 14 & 2012 & $\begin{array}{l}\text { AIC }<7.5 \%(58.5 \mathrm{mmol} / \mathrm{mol}) \\
\mathrm{FPG}=5-7.2 \mathrm{mmol} / \mathrm{L} \\
\text { Bedtime BG } 5-8.3 \mathrm{mmol} / \mathrm{L}\end{array}$ & $\begin{array}{l}\text { AIC }<8.0 \%(63.9 \mathrm{mmol} / \mathrm{mol}) \\
\mathrm{FPG}=5-8.3 \mathrm{mmol} / \mathrm{L} \\
\text { Bedtime BG } 5.6-10 \mathrm{mmol} / \mathrm{L}\end{array}$ & $\begin{array}{l}\text { AIC }<8.5 \%(69.4 \mathrm{mmol} / \mathrm{mol}) \\
\text { FPG }=5.6-10 \mathrm{mmol} / \mathrm{L} \\
\text { Bedtime } B G=6.1-11.1 \mathrm{mg} / \mathrm{dL}\end{array}$ \\
\hline IDF $^{10}$ & 2013 & $\begin{array}{l}\text { AIC }=7 \%-7.5 \% \\
(53.0-58.8 \mathrm{mmol} / \mathrm{mol})\end{array}$ & $\begin{array}{l}\text { AIC }=7 \%-8 \%(53.0-63.9 \mathrm{mmol} / \mathrm{mol}) \\
\text { up to } 8.5 \%(69.4 \mathrm{mmol} / \mathrm{mol})\end{array}$ & Avoid symptomatic hyperglycemia \\
\hline Diabetes UK ${ }^{36}$ & 2011 & \multicolumn{3}{|c|}{ Care home residents: $\mathrm{AIC}=7-8 \%(53.0-63.9 \mathrm{mmol} / \mathrm{mol}), \mathrm{FPG}=7-8.5 \mathrm{mmol} / \mathrm{L}$, random BG $<9 \mathrm{mmol} / \mathrm{L}$} \\
\hline IAGG/EDWPOP'3 & 2012 & \multicolumn{3}{|c|}{ In general, $\mathrm{A} I \mathrm{C}=7 \%-7.5 \%(53.0-58.8 \mathrm{mmol} / \mathrm{mol})$, avoid random BG $>1 \mathrm{l} \mathrm{mmol} / \mathrm{L}$} \\
\hline $\begin{array}{l}\text { Canadian Diabetes } \\
\text { Association }{ }^{15,38}\end{array}$ & 2013 & \multicolumn{3}{|c|}{$\begin{array}{l}\text { Limited life expectancy, high level of functional dependency, advanced comorbidities: AIC 7.I\%-8.5\% } \\
(54.0-69 \mathrm{mmol} / \mathrm{mol})\end{array}$} \\
\hline DCPNS/PATH, Canada ${ }^{16}$ & 2013 & \multicolumn{3}{|c|}{ Frail older adults: AIC =8\%-12\% (63.9-107.7 mmol/mol), avoid symptomatic hyperglycemia } \\
\hline
\end{tabular}

Abbreviations: BG, blood glucose; DCPNS/PATH, Diabetes Care Program of Nova Scotia and the Palliative and Therapeutic Harmonization Program; FPG, fasting plasma glucose; ADA, American Diabetes Association; AGS, American Geriatric Society; CHCF, California HealthCare Foundation; EDWPOP, European Diabetes Working Party for Older People; IAGG, International Association of Gerontology and Geriatrics; IDF, International Diabetes Federation; VA/DoD, Veterans Affairs/Department of Defense; NA, not applicable; AIC, glycated hemoglobin.

that higher A1C goals be set for older adults. . $^{10,12,14,16,19-21,36,38}$ Table 2 presents the glycemic targets according to different categories indicated by guidelines worldwide.

For reasons mentioned previously, less stringent glycemic targets have been suggested from recently developed guidelines. ${ }^{10,12,14,38}$ However, when the emphasis is made on less stringent glycemic control, it is likely to exacerbate clinical inertia, promote physician's attempts to withdraw antidiabetic agents, and, in turn, put elderly patients at high risk for sustained hyperglycemia and associated complications, such as incontinence, dehydration, hyperglycemic crisis, cognitive decline, visual disturbances, zinc loss, poor lower extremity performance, reductions in muscle mass, falls, and consequences of dependence. ${ }^{22,39-42}$ Physicians should keep in mind that older adults are at higher risk of hyperglycemic hyperosmolar syndrome than younger adults because of the altered perception of thirst that precludes their water intake when dehydrated, impaired functional status that limits their ability to access water, and impaired cognition that restricts their expression of thirst. ${ }^{43}$ Preventing incidence of diabetes-related comorbidities is also important in reducing the deterioration in physical disability. ${ }^{44}$ Thus, efforts to prevent physical disability should start from early stages, immediately after the diagnosis of diabetes. ${ }^{45}$

Higher glycemic variability, independent of traditional markers for glycemic control, such as A1C, fasting plasma glucose, and postprandial glucose, was associated with increased oxidative stress, increased inflammatory markers, and impaired cognitive function. ${ }^{46,47}$ To prevent frailty and cognitive decline and to prevent sustained hyperglycemia and consequent microvascular complications, minimizing glycemic variability may be equally important as preventing hypoglycemia in elderly diabetic patients. ${ }^{48}$

Is lower A1C really detrimental to the older patients? The ACCORD trial revealed a lesser known aspect that hypoglycemia is found more in individuals with higher A1C levels rather than those with lower A1C levels. Also, it was found that mortality was associated with higher A1Cs and nonimproved patients in the intensive group but not associated with hypoglycemia. ${ }^{49}$ Evidence revealed that hypoglycemic episodes are common in older patients with $\mathrm{A} 1 \mathrm{C} 8.0 \%$ (63.9 mmol/ $/ \mathrm{mol})$ or greater. Thus, raising the A1C targets may not prevent hypoglycemia in this population. ${ }^{50}$ There is no strong evidence that higher $\mathrm{A} 1 \mathrm{C}$ levels were beneficial for older adults. Thus, to achieve benefit from good glycemic control without increasing the risk of hypoglycemia in older adults, it would be better for physicians to follow a safe intensification process with appropriate selection of drugs with low glycemic variability, rather than raising A1C goals. ${ }^{49,51}$ If it can be achieved safely without an increase of hypoglycemia or other adverse events, A1C should be as normal as possible. Finally, all biopsychosocial aspects of older patients should be comprehensively evaluated, rather than treating the $\mathrm{A} 1 \mathrm{C}$ alone. ${ }^{52}$ 


\section{How to select antidiabetic therapies considering the characteristics of older adults}

Aging is characterized by a progressive impairment in carbohydrate tolerance, possibly related to disorderly insulin release, reduced insulin production and reduced glucagonlike peptide 1 (GLP-1) secretion, increased adiposity, sarcopenia, and physical inactivity. ${ }^{14,53,54}$ Relative contribution of postprandial glucose is higher than that of fasting glucose in older people..$^{55}$ These important features provide clues in selecting antidiabetic therapies that are more efficacious in postprandial glucose control for older adults.

Both morbidity and mortality in the elderly are independently predicted by the duration of diabetes and advancing age. Coronary artery disease and hypoglycemia were the most common complications in the elderly, both in short- and long-lasting diabetes. ${ }^{56}$ Elderly patients are more vulnerable to hypoglycemia due to age-related impairment of liver and renal function, leading to slightly decreased gluconeogenesis, ${ }^{18}$ altered drug elimination, and influence of drug interaction from polypharmacy. ${ }^{57}$ The hypoglycemia counterregulartory mechanism is defective in older people. Compared to those of healthy young adults, the responses of glucagon to hypoglycemia are lower in healthy elderly individuals and to a greater degree in older adults with diabetes. ${ }^{11}$ However, the response of glucagon to hypoglycemia is similar in middle-aged patients and older patients with diabetes. ${ }^{58}$ Older people are aware of hypoglycemia at a variable threshold between $5 \mathrm{mmol} / \mathrm{L}$ and $9 \mathrm{mmol} / \mathrm{L}$, which is higher than the usually defined $<4 \mathrm{mmol} / \mathrm{L}$. However, the symptoms they present are nonspecific rather than typical autonomic symptoms, and are generally presented as an unwell feeling. ${ }^{58,59}$ These nonspecific symptoms may be misinterpreted in older patients as presentation of coexisting illnesses. ${ }^{60}$

Uncontrolled hyperglycemia, repetitive hypoglycemia, and greater glucose variability are associated with worse cognition. ${ }^{46}$ Therefore, choosing effective antidiabetic therapies with relatively low risk for hypoglycemia and low glucose variability is very important in older adults. ${ }^{15}$ The principles of medication choice for older patients with T2DM are primarily the same as for younger adults, with special considerations in frailty, sarcopenia, cognition, and functional status. For the diabetic elders with unintentional body weight (BW) loss, sarcopenia, or sarcopenic obesity, the focus should be on avoiding medications with overt gastrointestinal side effects, which may aggravate the condition of malnutrition, worsening the frailty status. For those with cognition problems, efforts should be made to reduce regimen complexity and to avoid overt hyperglycemia and hypoglycemia. For those in end-of-life care, antidiabetic medications are aimed at avoiding symptomatic hyperglycemia with higher tolerable glycemic levels. After risk and benefit evaluations, some experts suggest metformin or dipeptidyl peptidase-4 (DPP4) inhibitors as drugs of choice for the elderly. ${ }^{12,41}$ In Table 3, we summarize the antidiabetic drugs with the considerations we mentioned above. Applications of antidiabetic therapies in different categories are summarized in Table 4. Interaction of oral antidiabetic drugs (OADs) and drugs used in common comorbidities are summarized in Table 5 for prescribing reference. ${ }^{61,62}$

Table 3 Comparisons of current options in glycemic control

\begin{tabular}{|c|c|c|c|c|c|}
\hline Options & $\begin{array}{l}\text { Hypoglycemia } \\
\text { risks }\end{array}$ & $\begin{array}{l}\text { Glycemic } \\
\text { variability }\end{array}$ & Costs & $\begin{array}{l}\text { Treatment } \\
\text { complexity }\end{array}$ & Special considerations \\
\hline Diet & Low & Reduced & Low & Variable & Balanced between glycemic control and nutrition status \\
\hline Exercise & Low & Reduced & Low & Low & Individualized planning, muscle strengthening \\
\hline BW reduction & Low & No data & Low & Variable & Not applicable to frail adults with or without malnutrition \\
\hline Metformin & Low & No change & Low & Low & $\begin{array}{l}\text { Be cautious in advanced CKD, CHF, frailty, malnutrition, and } \\
\text { sarcopenia; preserve skeletal muscle }\end{array}$ \\
\hline TZD & Low & No change & Moderate & Low & Preserve skeletal muscle; increased risk of fracture, $\mathrm{CHF}$ \\
\hline SU & High & No change & Low & Variable & Avoid glyburide/glibenclamide \\
\hline Meglitinides & Moderate & Reduced & Moderate & High & Should not combine with SU or AGl, drug interactions \\
\hline DPP4-i & Low & Lowest & Moderate & Low & Effective with preserved $\beta$-cell function \\
\hline GLPI-RA & Low & Lowest & High & Moderate & Effective with preserved $\beta$-cell function \\
\hline AGI & Low & Reduced & Moderate & High & Gastrointestinal side effects, social problems \\
\hline Insulin & High & Variable & Variable & Variable & Long-acting insulin analogs are suggested \\
\hline
\end{tabular}

Abbreviations: AGl, alpha glucosidase inhibitors; BW, body weight; CHF, congestive heart failure; CKD, chronic kidney disease; DPP4-i, dipeptidyl peptidase-4 inhibitors; GLPI-RA, glucagon-like peptide-I receptor agonists; SU, sulfonylurea; TZD, thiazolidinediones. 
Table 4 Comparisons of current options in glycemic control based on different categories

\begin{tabular}{|c|c|c|c|c|c|}
\hline \multirow[t]{3}{*}{ Options } & \multicolumn{5}{|l|}{ Categories } \\
\hline & \multicolumn{2}{|l|}{ Functionally independent } & \multicolumn{2}{|l|}{ Functionally dependent } & \multirow[t]{2}{*}{ End-of-life care } \\
\hline & Newly diagnosed & Long lasting & Frail & Dementia & \\
\hline Diet & Carbohydrates restriction & Carbohydrates restriction & Adequate calories, proteins & Adequate calories & Adequate calories \\
\hline Exercise & Muscle strengthening & Muscle strengthening & Muscle strengthening & Activities & Activities \\
\hline BW & Maintain healthy BW & Maintain healthy BW & Avoid BW loss & Avoid BW loss & Avoid BW loss \\
\hline \multirow[t]{2}{*}{ Metformin } & First-line medication & First-line medication & Potentially beneficial ${ }^{\mathrm{a}}$ & First-line medication & May be considered \\
\hline & & & Potentially detrimental ${ }^{b}$ & & \\
\hline \multirow[t]{2}{*}{ TZD } & Second-line combination & Potentially beneficial ${ }^{\mathrm{a}}$ & Potentially beneficial ${ }^{\mathrm{a}}$ & Potentially beneficial $^{e}$ & May be considered \\
\hline & & Potentially detrimental ${ }^{c}$ & Potentially detrimental $^{d}$ & Potentially detrimental ${ }^{f}$ & \\
\hline \multirow[t]{2}{*}{ SU } & Second-line combination & May be considered & Alternative first line ${ }^{g}$ & May be considered & May be considered \\
\hline & Start low, go slow & May not be effective & Potential detrimental ${ }^{\mathrm{h}}$ & Once daily, start low & \\
\hline \multirow[t]{2}{*}{ Meglitinides } & Second-line combination & May be considered & May be considered & Potentially detrimentali & May be considered \\
\hline & & May not be effective & & & \\
\hline \multirow[t]{2}{*}{ DPP4-i } & Second-line combination & May be considered & May be considered & May be considered, & May be considered \\
\hline & & May not be effective & & once daily & \\
\hline \multirow[t]{2}{*}{ GLPI-RA } & Second- or third-line & May be considered & Potentially detrimental ${ }^{b}$ & May not be cost & May not be cost \\
\hline & combination & May not be effective & & effective & effective \\
\hline \multirow[t]{2}{*}{ AGI } & Second-line combination & May be considered & Potentially detrimental ${ }^{b}$ & May be considered & May be considered \\
\hline & & May not be effective & & & \\
\hline Insulin & Second-line combination, & May need prandial insulin & Long-acting analogs & Long-acting analogs & $\mathrm{NPH}$ may be enough \\
\hline
\end{tabular}

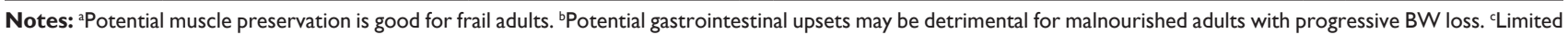

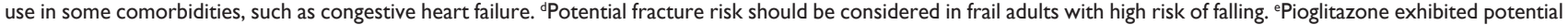
cognitive improvement in mild AD. 'Rosiglitazone is associated with cognitive decline. ${ }^{8}$ For elderly not eligible for metformin use, low dose initiated SU may be alternative

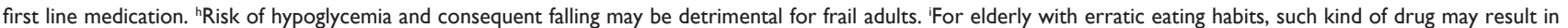
higher risk of hypoglycemia.

Abbreviations: AGI, alpha glucosidase inhibitors; BW, body weight; DPP4-i, dipeptidyl peptidase-4 inhibitors; GLPI-RA, glucagon-like peptide-I receptor agonists; SU, sulfonylurea; TZD, thiazolidinediones; NPH, neutral protamine Hagedorn.

\section{Options of therapy in elderly patients First line: lifestyle interventions and metformin \\ Lifestyle interventions}

The importance of lifestyle interventions cannot be overemphasized. An increase of one healthy behavior was associated with a decrease in A1C level of $>1.0$ percentage point in older adults with diabetes. ${ }^{63}$ Diet and exercise remain the cornerstones of diabetes management. While decreasing the amount of carbohydrates, diet should be designed with adequate calories to maintain ideal $\mathrm{BW}$ and lean muscle mass and to prevent sarcopenia or sarcopenic obesity and consequent frailty in the elderly patients. Optimizing weight in adults with diabetes is an important factor in predicting better glycemia. ${ }^{63}$ Functionally independent obese elderly patients should be encouraged to maintain a healthy BW. However, compared to those who are overweight or obese, the impact of weight change in those with relatively normal weight may be complicated. ${ }^{64}$ Most of the studies reviewed suggest that poor glucose regulation is associated with weight loss. ${ }^{65}$ Restricted diet should be avoided in malnourished elderly patients. ${ }^{13}$ Nutrition status should be thoroughly evaluated in elderly diabetic patients, with individualized nutritional planning, focusing on adequate hydration, optimal calories, and protein intake to maintain nutrition and functional status and prevent muscle loss. ${ }^{8,10,22,36,37}$ Complex carbohydrates and fiber are good for decreasing glycemic excursions after meals. ${ }^{39}$ The average daily protein intake should reach $1.0-1.2 \mathrm{~g} / \mathrm{kg} \mathrm{BW} /$ day to maintain and regain lean body mass and function and to prevent sarcopenia and frailty in older people. ${ }^{66}$ Protein-enriched diet with concomitant muscle training may preserve or even enhance muscle mass and strength. ${ }^{67}$ This may also improve functional status and muscular glucose uptake. ${ }^{68}$

Physical activity is also encouraged in all adults, but should be individualized to fit individual's medical and physical status with special considerations of degenerated joints, diabetic neuropathy, and retinopathy. Both endurance- and resistance-type exercises are recommended as they are safe and tolerable. ${ }^{66}$ Cardiovascular risks should be evaluated before introducing an exercise program..$^{39}$ Exercise-induced hypoglycemia should be carefully assessed in older diabetic 
Table 5 Drug interactions between antidiabetic agents and drugs used for the most common comorbidities in the elderly

\begin{tabular}{|c|c|c|c|c|c|c|}
\hline & Metformin & Sulfonylureas & Meglitinides & Pioglitazone & DPP4 inhibitors & Acarbose \\
\hline Gemfibrozil & & $\begin{array}{l}\text { IC } 4 \text { effect } \\
\text { of glyburide }\end{array}$ & $\begin{array}{l}\mathrm{XX} \uparrow \text { concentration } \\
\text { of repaglinide }\end{array}$ & $\begin{array}{l}\text { ID } 4 \text { concentration } \\
\text { of pioglitazone }\end{array}$ & & \\
\hline Fenofibrate & & IC 4 effect of SU & & & & \\
\hline Statin & & $\begin{array}{l}\text { MC } 4 \text { concentration } \\
\text { of glyburide } \\
\text { (fluvastatin) }\end{array}$ & & $\begin{array}{l}\text { IC } \downarrow \text { concentration } \\
\text { of pioglitazone (atorvastatin) }\end{array}$ & & \\
\hline Aspirin & & IC 4 effect of SU & & & & \\
\hline Warfarin & & IC 4 effect of both & & & & $\begin{array}{l}\text { ID } 4 \text { risk of } \\
\text { bleeding }\end{array}$ \\
\hline $\begin{array}{l}\text { ACE } \\
\text { inhibitors }\end{array}$ & $\begin{array}{l}\text { IC } 4 \text { risk of } \\
\text { hyperkalemic } \\
\text { lactic acidosis }\end{array}$ & & & & $\begin{array}{l}\text { IC } 4 \text { risk of } \\
\text { angioedema }\end{array}$ & \\
\hline DHP-CCB & $\begin{array}{l}\text { MC } \uparrow \text { absorption } \\
\text { of metformin } \\
\text { (nifedipine) }\end{array}$ & & & $\begin{array}{l}\text { SD } \downarrow \text { exposure to nifedepine } \\
\text { IC } \downarrow \text { efficacy of amlodipine }\end{array}$ & & $\begin{array}{l}\text { IC } \downarrow \text { glucose } \\
\text { control } \\
\text { (nifedepine) }\end{array}$ \\
\hline ND-CCB & $\begin{array}{l}\text { SC } 4 \text { effectiveness } \\
\text { of metformin } \\
\text { (verapamil) }\end{array}$ & & & & $\begin{array}{l}\text { IC } \uparrow \text { concentration } \\
\text { of saxagliptin }\end{array}$ & \\
\hline Digoxin & $\begin{array}{l}\text { IC } 4 \text { metformin } \\
\text { concentration }\end{array}$ & & & & $\begin{array}{l}\text { MC } 4 \text { digoxin } \\
\text { level (sitagliptin) }\end{array}$ & $\begin{array}{l}\text { IC } \downarrow \text { digoxin } \\
\text { concentration }\end{array}$ \\
\hline Amiodarone & & $\begin{array}{l}\mathrm{IC} \uparrow \mathrm{SU} \\
\text { concentration }\end{array}$ & $\begin{array}{l}\text { IC } 4 \text { nateglinide } \\
\text { concentration }\end{array}$ & $\begin{array}{l}\text { IC } 4 \text { exposure } \\
\text { of amiodarone }\end{array}$ & $\begin{array}{l}\text { IC } 4 \text { saxagliptin } \\
\text { exposure }\end{array}$ & \\
\hline \multirow[t]{2}{*}{ Thiazide } & ID $\downarrow$ effectiveness c & of all anti-diabetic agent & & & & \\
\hline & Metformin & Sulfonylureas & Pravastatin Ezetimibe & Olmesartan & Diltiazem & Amiodarone \\
\hline Colesevelam & $\begin{array}{l}\text { IC } 4 \text { exposure } \\
\text { to metformin-XR }\end{array}$ & $\begin{array}{l}\text { ID } \downarrow \\
\text { SU absorption }\end{array}$ & $\begin{array}{ll}\text { ID } \downarrow & \text { ID } \downarrow \\
\text { absorption } & \text { absorption } \\
\text { of pravastatin } & \text { of ezetimibe }\end{array}$ & $\begin{array}{l}\text { ID } \downarrow \\
\text { absorption } \\
\text { of olmesartan }\end{array}$ & $\begin{array}{l}\text { ID } \downarrow \\
\text { bioavailability } \\
\text { of diltiazem }\end{array}$ & $\begin{array}{l}\text { SD } \downarrow \\
\text { bioavailability of } \\
\text { amiodarone }\end{array}$ \\
\hline
\end{tabular}

Notes: Severity: X contraindicated; S major; I moderate; M minor. Risk rating: X: avoid combination; D: consider therapy modification; C: monitor therapy. Reliability rating: good; 1 probable; fair or theoretical.

Abbreviations: DHP-CCB, dihydropyridine calcium channel blocker; ND-CCB, non-dihydropyridine calcium channel blocker; SU, sulfonylurea; DPP4, dipeptidyl peptidase-4; $A C E$, angiotensin-converting enzyme; INR, international normalized ratio.

patients who are prescribed a medication regimen with higher risk of hypoglycemia. ${ }^{39}$

\section{Biguanides (metformin)}

Metformin has gained increasing acceptance as first-line therapy along with lifestyle modification to achieve optimal glycemic goals. It improves insulin resistance, decreases hepatic gluconeogenesis, and induces some BW loss, with low potential for hypoglycemia. ${ }^{39}$ A longitudinal cohort study showed that older men with diabetes using metformin or thiazolidinediones (TZDs) lost less lean body mass compared with those with untreated diabetes or treated with other antidiabetic agents. ${ }^{69}$ This result is potentially beneficial for older adults, even in the frail elderly patients, whose muscle mass is lost with aging and accelerated with impaired fasting glucose and diabetes. ${ }^{69}$

However, there are still some special considerations that preclude older adults from using metformin as a first-line therapy. The well-known side effects of metformin, namely, gastrointestinal discomfort such as anorexia, nausea, vomiting, diarrhea, and constipation, are a main concern in older adults who are frail, underweight, anorexic, and malnourished. . $070,71^{-}$ Another general concern with metformin is its risk for lactic acidosis, which is still put on the "black-box" warning regarding its use in advanced renal insufficiency (serum creatinine $\geq 132.6 \mu \mathrm{mol} / \mathrm{L}$ in men or $\geq 123.7 \mu \mathrm{mol} / \mathrm{L}$ in women or estimated glomerular filtration rate $<30 \mathrm{~mL} / \mathrm{min}$ ), hepatic disease, congestive heart failure, and advanced age ( $>80$ years old). It is also suggested in the package insert that metformin should be withdrawn in critical illness, persistent diarrhea, hypotension, and two days prior to contrast-enhanced imaging studies for fear of acute kidney injury and consequent accumulation of metformin in these conditions. In clinical practice, controversy exists about the association between lactic acidosis and the use of metformin. ${ }^{72-76} \mathrm{~A}$ Cochrane review of 347 studies in T2DM patients concluded that metformin is not associated with an increased risk of lactic acidosis, or increased levels of lactate, compared to the non-metformin group..$^{77}$ The causal relationship of serum concentration of metformin and lactate level is not well established. ${ }^{78}$ 
A prospective, randomized observational study demonstrated that metformin could be safely continued even in patients with creatinine levels up to $221 \mu \mathrm{mol} / \mathrm{L}$ without increasing the incidence of lactic acidosis. ${ }^{73}$ A retrospective cross-sectional study also showed that age per se was not associated with increase of lactate level in metformin users. ${ }^{79}$ Based on existing evidence, the benefits of metformin therapy outweigh the potential risks. ${ }^{74}$ It is suggested to start metformin from lower doses and reduce the maximum dose by about $50 \%$ in patients with eGFR $<60 \mathrm{~mL} / \mathrm{min}$, rather than strictly avoid the drug, even in oldest-old adults. ${ }^{80}$

Patients taking metformin had lower vitamin $\mathrm{B}_{12}\left(\right.$ vitB $\left._{12}\right)$ levels than those not taking metformin. ${ }^{81}$ In a multicenter, randomized, placebo-controlled trial, metformin treatment for 4.3 years was associated with decrease in vitB ${ }_{12}$ concentration of $19 \%$ and decrease in folate concentration of $5 \% .{ }^{82}$ Regular measurement of vitB ${ }_{12}$ and folate level might be necessary in elderly diabetic patients who received longterm metformin therapy. Early recognition of the issue with appropriate supplementation may prevent development of the consequence of vitB ${ }_{12}$ deficiency, such as macrocytic anemia and neuropathies.

\section{Second-line or alternative first-line therapy}

In patients contraindicated or intolerable to metformin therapies, all antidiabetic drugs could be used as an alternative first-line therapy, judging by the characteristics of each individual, the regulation of national health insurance, and the specific action of each drug as described below. ${ }^{83}$

\section{Thiazolidinediones}

The TZDs, which are insulin sensitizers and which act through activation of peroxisome proliferator-activated receptors gamma, are effective in lowering fasting glucose level through increased peripheral insulin sensitivity, especially of muscle and adipocytes. Pioglitazone, when prescribed in patients older than 65 years, had similar effectiveness and safety as in younger adults. ${ }^{84}$ It was also suggested that a combination of pioglitazone and sitagliptin improved $\alpha$-cell and $\beta$-cell functions, thus reducing postprandial glucose excursions more than by either treatment alone. ${ }^{85}$ Considering the low incidence of hypoglycemia of each class of the drugs, this combination seemed promising in glycemic control for older adults. However, safety profiles of TZDs are still a concern. ${ }^{86,87}$ It should not be used in patients with active liver disease. Increased rates of bone fractures was observed in elderly women taking rosiglitazone but not in men from the A Diabetes Outcome Progression Trial (ADOPT). ${ }^{88,89}$ However, increased fractures were observed at the humerus, hand, and foot, rather than the typical osteoporotic sites. A similar finding was also found in the PROactive trial..$^{90}$ To date, the mechanism explaining these results is still unclear. The effect of pioglitazone on bone mineral density is reported as a trend of decrease in proximal femur, hip, and lumbar spine in diabetic women, but no effect in prediabetic women. There were no changes in biochemical markers of bone turnover. ${ }^{91,92}$ As the clinical and pathophysiological evidence still advises the association between TZDs and fractures, its application in older adults should be made with caution..$^{93,94}$

Another concern is its effect on cognition. As reported in the ACCORD-MIND cohort, exposure to rosiglitazone is associated with greater decline in cognitive performance compared with insulin therapy..$^{95}$ Despite the current evidence against the use of rosiglitazone in Alzheimer's disease (AD), pioglitazone exhibited cognitive and functional improvement in mild AD. ${ }^{96-98}$ More evidence is needed to make recommendations about the use of pioglitazone in AD.

TZDs are also related to fluid retention. When used in patients with diabetic macular edema, worsening of the condition was reported. ${ }^{99}$ Current evidence suggests that TZDs could still be safely continued in patients without macular edema. ${ }^{100}$ However, this feature limits its application in patients with class III or IV congestive heart failure. ${ }^{101-103}$ The risk of ischemic stroke, myocardial ischemia, and heart failure is still inconclusive in rosiglitazone and pioglitazone. ${ }^{101,104-108}$ Prescription of rosiglitazone in some areas is highly restricted now.

Despite the positive effect of TZDs on glycemic control, lean body mass, cognition, and low risk of hypoglycemia, drawbacks such as increased risk of fractures, probable macular edema, heart failure, and fluid retention exist. Application of TZDs in older diabetic adults needs to be carefully evaluated for its risk/benefit ratio. Newer generation TZDs, termed as selective peroxisome proliferator-activated receptors gamma modulators, which may minimize the unwanted effects of current TZDs, are being developed and may be promising in the future. ${ }^{86}$

\section{Sulfonylureas}

Insulin secretagogues, which stimulate insulin release from pancreatic $\beta$-cells, have been popular for a long time because of their good efficacy and relatively low cost. As pancreatic $\beta$-cell function decreases with aging, insulin secretagogues 
are theoretically a good choice to enhance insulin secretion in older adults. ${ }^{54}$ Risk of hypoglycemia among elderly patients treated with sulfonylureas (SU), especially glyburide (glibenclamide) and chlorpropamide, is higher than among younger adults, which is associated with more hypoglycemia-related hospitalizations. ${ }^{109,110}$ Higher risk of hypoglycemia related to SU use is associated with impaired renal function, impaired hepatic function, recent hospitalization, polypharmacy, alcohol use, and caloric restriction in older adults. ${ }^{111}$ Sensitivity to SU may increase, especially in those aged over 80 , which makes the oldest-old more vulnerable to hypoglycemia. ${ }^{36}$ Despite these drawbacks, there is no need to abruptly withdraw SU from all older adults. Its once-daily dosage form is potentially good for improving compliance of older adults and for minimizing dosing errors. ${ }^{71}$ Guidelines developed all over the world suggest avoidance of only glyburide in older adults, which was associated with the most long-lasting, life-threatening hypoglycemic events..$^{10}$ The most important thing in prescribing SU in older adults is to follow the principle of starting SU from lowest dose, to slowly titrate to the individualized target, and to closely monitor any hypoglycemia symptoms, especially in elderly patients whose pancreatic $\beta$-cell function is only mildly impaired. SUs may still fail to be effective in some patients, as they develop pancreatic $\beta$-cell failure, especially in elderly patients with long-lasting diabetes, which makes it an appropriate substitute for insulin in patients whose glycemic targets are not stringent. 18,36

\section{Meglitinides (repaglinide and nateglinide)}

The meglitinides are rapid-acting insulin secretagogues with a short duration of action, and are aimed at increasing prandial insulin secretion. ${ }^{12}$ Nateglinide should not be used with SU because of competitive binding of SU receptors. A randomized, open-label, crossover trial suggested that repaglinide is safe and effective with lower risk of hypoglycemia compared with SU in older patients with borderline poor glycemic control. ${ }^{113}$ Hypoglycemia is related to missed meals, so meglitinides should be taken within 30 minutes before meals. Therefore, meglitinides should be prescribed with caution in the elderly patients with cognitive impairment and erratic eating habits. ${ }^{10}$ Hepatic and renal insufficiency may prolong the action of repaglinide, resulting in higher risk of hypoglycemia in these conditions. ${ }^{70}$ Disadvantages include relatively high cost, frequency of administration, and strict regulation of time of taking medicine, which contribute to the complexity of polypharmacy in older adults. ${ }^{39,71}$

\section{Alpha-glucosidase inhibitors}

Alpha-glucosidase inhibitors (AGIs) delay absorption of carbohydrates and result in decreased postprandial glucose excursions, improvement of glycemic variability without increased oxidative stress, and possible improvement of $\beta$-cell response. ${ }^{12,114,115}$ Maximal antihyperglycemia is achieved with lower doses ( $25 \mathrm{mg}$ before meals) in elderly patients than their younger counterparts. ${ }^{116}$ Moreover, AGIs may increase insulin sensitivity in diabetic elderly patients. ${ }^{117}$ They are effective in elderly overweight type 2 diabetic patients. ${ }^{118}$ They are well tolerated in older adults even with multiple comorbidities with a low incidence of hypoglycemia as monotherapy. AGIs also reduced the risk of postprandial hypoglycemia and late hypoglycemia in older adults with T2DM who eat rice porridge as main meal, due to impaired chewing function. ${ }^{119}$ When hypoglycemia occurs in regimens combined with AGIs, it should be treated with oral glucose because other complex carbohydrates will not relieve the event. ${ }^{39}$ Special education should be imparted to the elderly patients and their family members to manage such hypoglycemic conditions. Further, if AGIs are prescribed with prandial insulin, mismatch between peak serum glucose levels and peak prandial insulin levels may occur, placing patients at increased risk for hypoglycemia. ${ }^{71}$ The most common adverse events are gastrointestinal disturbances, especially flatulence, abdominal distension, diarrhea, abdominal pain, and abdominal discomfort, which preclude AGIs application in the elderly patients. ${ }^{18,120-123}$ The clinical response of AGIs depends on preserved $\beta$-cell function. That is, AGIs are more effective in newly diagnosed diabetes and less effective in long-standing diabetes with severely impaired insulin secretion. ${ }^{12}$ This feature is important in determining whether AGIs should be prescribed in older adults. Another concern is that AGIs should be taken with meals, which increases the complexity of the medication regimen and may lead to nonadherence. ${ }^{124}$

\section{Incretin-based therapies}

Incretin-based therapies have drawn increasing attention in recent years because of their properties of enhancing glucose-dependent insulin secretion after ingestion of food. ${ }^{22}$ Both GLP-1 and glucose-dependent insulinotropic peptide are degraded rapidly by DPP4, resulting in short plasma half-lives. GLP-1 suppresses glucagon secretion, delays gastric emptying, increases satiety, and decreases food intake. ${ }^{22}$ There are two classes of drugs focusing on incretin effect, namely, DPP4 inhibitors and GLP-1 receptor agonists. 


\section{DPP4 inhibitors}

This drug class inhibits DPP4, and thus prolongs the action of GLP-1 and glucose-dependent insulinotropic peptide in diabetic patients whose incretin response is impaired. ${ }^{71}$ Among the currently available DPP4 inhibitors, sitagliptin, vildagliptin, saxagliptin, linagliptin, and alogliptin have been confirmed to be well tolerated in older adults with few gastrointestinal side effects and little effect on BW, with similar efficacy as younger adults, and can be safely used in renal insufficiency with labeled dose adjustment for each drug. ${ }^{125-131}$ DPP4 inhibitors resulted in reductions in A1C for patients whose baseline A1C levels were higher. ${ }^{130}$ These excellent tolerability profiles, low risk of hypoglycemia, and once-daily dosing make this drug class suitable for frail and debilitated elderly patients. ${ }^{7,12,22}$

DPP4 inhibitors enhance the effect of insulin secretion stimulated by $\mathrm{SU}$, and thus increase the risk of hypoglycemia when used in combinations with SU. ${ }^{129}$ This characteristic also indicates that DPP4 inhibitors are efficacious with preserved $\beta$-cell insulin secretion, and may be primarily effective early in the course of diabetes with mild hyperglycemia. ${ }^{132,133}$ Conversely, DPP4 inhibitors might be ineffective in elderly patients with long-lasting T2DM and poorly preserved $\beta$-cell insulin secretion. Another concern is their high expense, which may make them unavailable in some countries. ${ }^{10}$

\section{GLP-I receptor agonists}

This drug class acts on the GLP-1 receptor directly with long duration due to its resistance to degradation by DPP. GLP-1 receptor agonists are effective in glycemic control and are well tolerated without increasing the risk of hypoglycemia in older patients. ${ }^{134-136}$ In addition to their glucose-lowering effects, GLP-1 receptor agonists delay gastric emptying and increase satiety, resulting in weight loss, in particular reductions in subcutaneous fat mass. ${ }^{137}$ Liraglutide also resulted in slight reductions of visceral fat mass in pioglitazone users. ${ }^{137}$ Both liraglutide and exenatide ameliorate concomitant nonalcoholic fatty liver disease. ${ }^{137,138}$ The evidence of their impact on muscle mass is still lacking. However, just as the concern in DPP4 inhibitors, the effect of GLP-1 receptor agonists on $\mathrm{A} 1 \mathrm{C}$ reductions was also inversely related to diabetes duration, ie, to the preservation of $\beta$-cell function. ${ }^{139}$ Thus, the characteristics of GLP-1 receptor agonists might be beneficial to obese diabetic elders if used early in the course of diabetes. ${ }^{12,140}$ However, their weight-reducing effect and gastrointestinal side effects may be detrimental for the frail elderly patients with poor caloric intake and poor nutrition status. ${ }^{10,70,71}$ These drugs should be used with caution in diabetic elders who are undergoing unintentional weight loss, and who are malnourished or at high risk for malnutrition. Metabolism and excretion of liraglutide is not affected by renal impairment, even in patients with end-stage renal disease. ${ }^{141,142}$ Recommendations for use of liraglutide in patients with more advanced renal impairment are limited. ${ }^{143}$ Exenatide is excreted through the kidney, and is not recommended for use in severe renal impairment or end-stage renal disease. ${ }^{131}$

\section{Bile acid sequestrants}

Colesevelam hydrochloride was originally approved for treatment of hyperlipidemia; ${ }^{144}$ however, subsequent clinical trials demonstrated an improvement in glycemia for patients with T2DM. ${ }^{145-147}$ Colesevelam is a bile acid sequestrant designed to have a high affinity and capacity for binding to bile acids. ${ }^{148}$ Colesevelam is nonabsorbable by the body, and its distribution is confined to the digestive tract. Its hydrophilic and water-insoluble nature facilitates binding of bile acids in the intestine and excretion of these complexes in the feces. ${ }^{149}$ As a result, the body increases the conversion of cholesterol to bile acids, resulting in an uptake of lowdensity lipoprotein cholesterol (LDL-C) by the liver to the blood, thereby lowering serum LDL-C. Colesevelam as a monotherapy or add-on therapy for the treatment of T2DM can reduce A1C and LDL-C levels. ${ }^{150}$ Further, in T2DM patients aged 65 years and older, colesevelam treatment as an add-on therapy results in similar A1C reductions. ${ }^{151}$ Colesevelam is safe and well-tolerated in older adults, with certain mild to moderate gastrointestinal side effects including constipation and dyspepsia. ${ }^{151}$ An advantage of prescribing colesevelam to older diabetic patients is the low risk for hypoglycemic events. ${ }^{150}$

\section{Sodium glucose cotransporter 2 inhibitors}

The newest drug class for oral diabetic agents is the sodium glucose cotransporter 2 (SGLT2) inhibitors. ${ }^{152}$ SGLT2 inhibitors prevent the reabsorption of renal-filtered glucose levels, resulting in decreased blood glucose levels. ${ }^{153}$ SGLT2 inhibitors can be used as a monotherapy or dual and triple therapy for T2DM patients to moderately lower A1C levels $(0.5 \%-1.0 \%){ }^{154}$ Further, SGLT2 inhibitors have the added benefits of weight loss and improved blood pressure and lipid parameters. ${ }^{154-157}$ SGLT2 inhibitors are generally well tolerated among diabetic patients. ${ }^{158-161}$ Common adverse events include urinary tract infections, genital mycotic infections, hypotension/volume depletion, lipid alterations, hypoglycemia, and renal insufficiency. ${ }^{156,161-165}$ The efficacy and safety 
of SGLT2 inhibitors in elderly patients is consistent with younger patients; ${ }^{166}$ however, additional long-term studies are needed. Thus, the risks and benefits of SGLT2 inhibitors should be assessed in older patients on a case-by-case basis given the newness of the drug class. ${ }^{166}$

\section{Insulin}

Insulin therapy is inevitable when $\beta$-cell preservation is severely impaired due to advanced age or long-lasting T2DM. ${ }^{39}$ Early use of insulin may reduce glucotoxicity and restore function of $\beta$-cells. ${ }^{39}$ However, insulin is often underutilized in elderly patients due to concerns about hypoglycemia, misconceptions about insulin, social stigma, needle phobia, complexity of injection skills, low adaptation capacity, and, moreover, clinical inertia. ${ }^{70,167}$ Before initiating insulin therapy, comprehensive evaluation of psychosocial barriers, functional status (ie, visual acuity and manual dexterity), cognitive status, and financial ability to afford insulin and insulin-delivery supplies should be made to ensure safety, compliance, and effectiveness of insulin use. ${ }^{70}$

Conventional neutral protamine Hagedorn (NPH) insulin and regular insulin were not recommended due to variable bioavailability and nonphysiological pharmacokinetics that put patients in higher risk of hypoglycemia. ${ }^{70}$ Long-acting insulins degludec, glargine, and detemir are safer choices than NPH in older adults because of their lower risk of hypoglycemia, especially nocturnal hypoglycemia, which may contribute to cardiovascular morbidity and falls. ${ }^{168-172}$ Insulin degludec resulted in less hypoglycemia than insulin glargine even in long-duration diabetic patients, whose counterregulatory hormone responses were presumed to be weaker. ${ }^{169}$ Besides, insulin analogs are mostly delivered through insulin pens, which leads to improved adherence, accuracy of injection, quality of life, and decreased admissions for hypoglycemia. ${ }^{12,15,173,174}$

For elderly diabetic patients with inadequately controlled hyperglycemia, patients with early combinations of basal insulin had better glycemic control and less hypoglycemia than titration of oral antidiabetic drugs. ${ }^{175}$ In diabetic elders with poorly controlled glycemia, insulin therapy did not result in higher hypoglycemia events if glycemic targets were less stringent. ${ }^{176} \mathrm{~A}$ once-daily insulin regimen was also more preferred by an older population than more frequent dosing. ${ }^{177}$ Prandial insulin supplement in basal bolus regimen or premixed insulin may be appropriate in highly selected elderly patients with good functional reserve. ${ }^{70}$ Judicious use of insulin as an add-on therapy may improve mental health, quality of life, social functioning, treatment satisfaction, and caregiver strain in elderly diabetic patients with poor glycemic control. ${ }^{178}$

\section{Combinations of antidiabetic agents}

Considering the importance of avoiding hypoglycemia and managing postprandial hyperglycemia in elderly patients, some combinations may provide these desirable outcomes better than commonly used metformin plus SU in clinical practice. We summarize the results of randomized controlled trials comparing glycemic effect, hypoglycemia risk, and influence on BW among strategies of each combination in Table 6 and Figure 1. Current trials regarding drugs combination were not planned for the elderly patients except for a few studies including the elderly patients as a subgroup for further analysis. ${ }^{179-184}$ As the risk of hypoglycemia is higher in older adults, combination strategies with less hypoglycemia risk in middle-aged adults may be more appropriate for older adults.

\section{Metformin plus DPP4 inhibitors}

When metformin monotherapy could not achieve glycemic target, DPP4 inhibitor was suggested as first add-on drug compared with SU, TZD, or insulin glargine in the elderly patients. Though not as effective as insulin glargine, combination of metformin with DPP4 inhibitors provided the favorable result of less hypoglycemia incidence. ${ }^{185}$ Compared with SU, DPP4 inhibitor results in similar improvement of $\mathrm{A} 1 \mathrm{C}$, but less hypoglycemia incidence and no weight gain. ${ }^{180-184,186-188}$ This combination also showed better glycemic variability, ${ }^{189,190}$ decrease of glucagon production, ${ }^{187}$ better $\beta$-cell function, ${ }^{188}$ better insulin resistance, ${ }^{187}$ and better cost-effectiveness than a combination of metformin with SU. ${ }^{179,191,192}$ Compared with TZD, combination with DPP4 inhibitors revealed similar glycemic control and hypoglycemia risk, but less weight gain. ${ }^{193-195}$ Compared with metformin plus SU, metformin plus TZD was the more tolerable combination due to less hypoglycemia incidence with similar glycemic control and BW gain. ${ }^{196-198}$

\section{Metformin plus SGLT2 inhibitors}

SGLT2 inhibitors are newly approved drugs without experience on long-term effect and safety. Randomized controlled studies demonstrated that combination with canaglifozin is at least not inferior to combination with glimepiride or sitagliptin in glycemic control, but with less hypoglycemia incidence than glimepiride ${ }^{199}$ and more BW reduction than sitagliptin. ${ }^{200}$ This combination may provide favorable effects for elderly groups, but at the cost of more genitourinary tract 


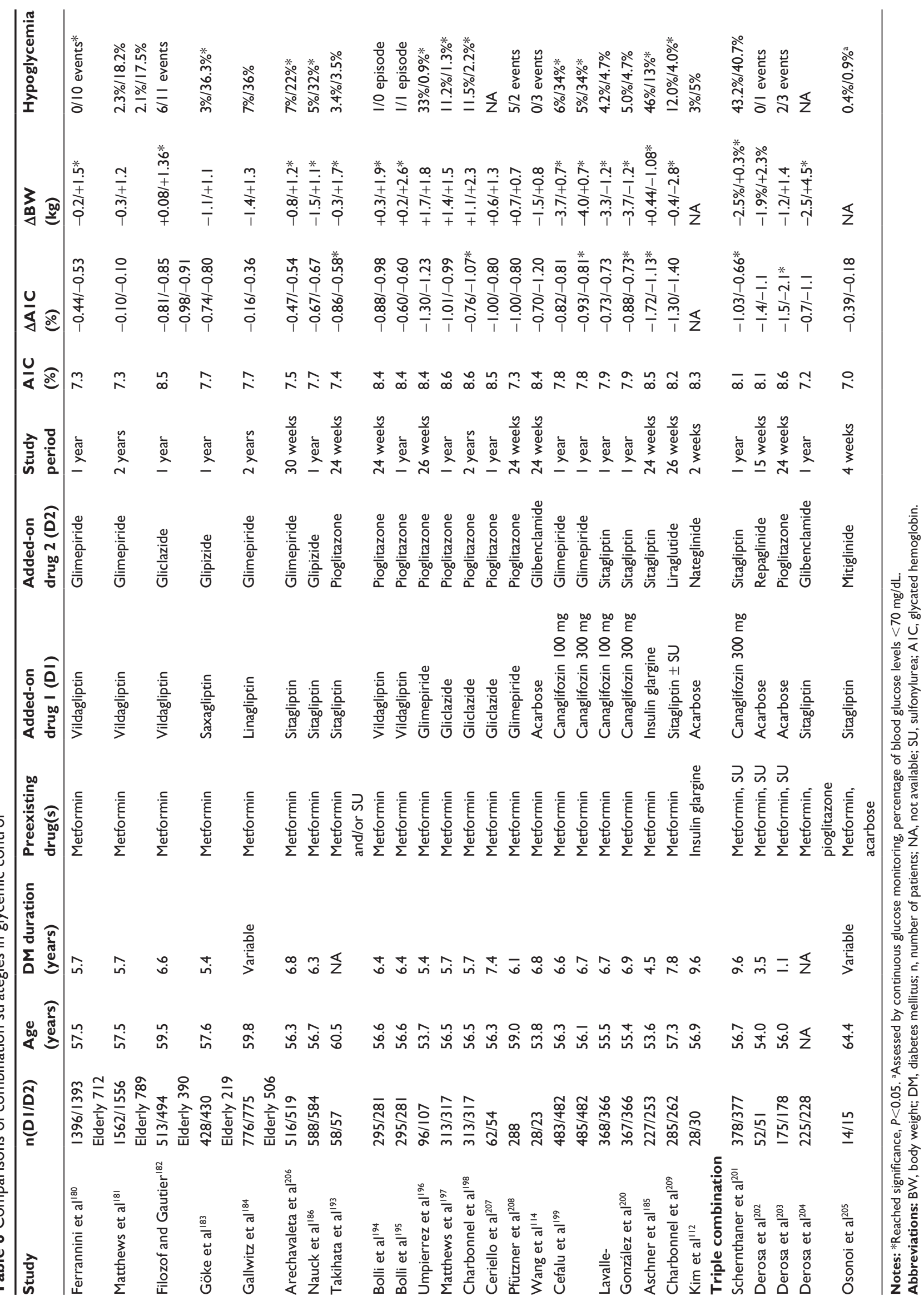




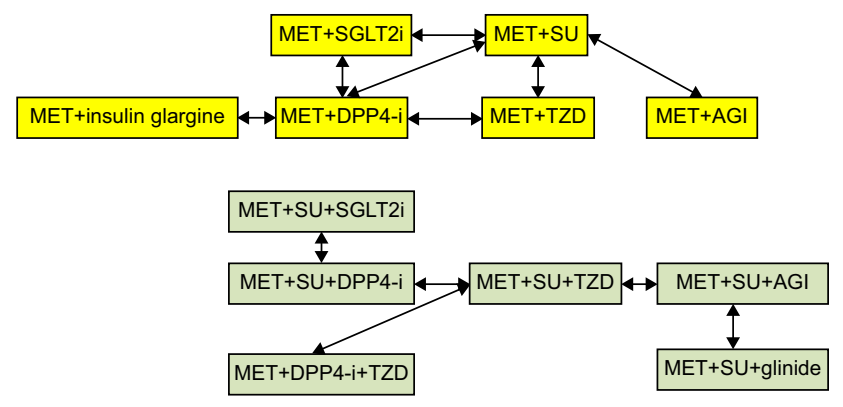

Figure I Comparison of combination therapies, studies including two drugs combination, and three drugs combination.

Abbreviations: AGI, alpha glucosidase inhibitors; DPP4-i, dipeptidyl peptidase-4 inhibitors; SU, sulfonylurea; TZD, thiazolidinediones; SGLT2i, sodium glucose cotransporter 2 inhibitor; MET, metformin.

infection. This risk should be balanced with other benefits during clinical practice.

\section{Metformin plus acarbose}

Effective on reduction of postprandial glucose excursion with low hypoglycemia risk makes AGIs an attractive second-line therapy in elderly patients, at least theoretically. However, there was only one study with a small sample size comparing acarbose and glibenclamide as second-line combination therapy. Though not significant, AGIs seemed less effective than SU in glycemic control but had a favorable effect on BW. ${ }^{114}$ Evidence was not adequate to make a suggestion due to limited studies.

\section{Triple combinations}

Studies on triple combinations were limited. Most of the dual combinations in clinical practice are metformin plus SU. Some randomized controlled trials enrolled patients in poor control with metformin plus SU and compared the effect of the third drug. Combination with canaglifozin $300 \mathrm{mg} /$ day was superior to sitagliptin in glycemic control and BW reduction without increased incidence of hypoglycemia. ${ }^{201}$ Acarbose had similar effects as repaglinide ${ }^{202}$ but was less effective than pioglitazone added on, despite favorable effect on BW control. ${ }^{203}$

\section{Metformin and pioglitazone plus DPP4 inhibitors}

If metformin and pioglitazone combinations were used as the first two OADs, DPP4 inhibitors and SU decreased A1C to a similar degree. DPP4 inhibitors had a neutral effect on BW compared with BW gain in SU group. This combination was more tolerable than combination with SU, such that no patients withdrew from the study due to hypoglycemia as compared with eleven patients in the SU arm. This combination also demonstrated better protection of $\beta$-cell secretion. ${ }^{204}$ These features were desirable for elderly patients.

\section{Metformin and acarbose plus DPP4 inhibitors or mitiglinide}

Despite the theoretical concern of the mismatch between peak glucose absorption and peak prandial insulin secretion in combination of acarbose with mitiglinides, a prospective randomized study revealed that daily blood glucose fluctuations were significantly improved without increase in incidence of hypoglycemia. ${ }^{205}$ For elderly patients poorly controlled with metformin monotherapy, a combination of AGIs plus DPP4 inhibitors or AGIs plus mitiglinide may be an attractive add-on choice.

\section{Conclusion}

The target of glycemic management in elderly patients with T2DM has been focused on preventing frailty and preserving functional independence. Recommendations from guidelines worldwide suggest higher A1C targets than younger adults. However, evidence suggests that better glycemic control in older adults is equally important in maintaining functional independence and cognition in order to prevent hypoglycemia in such populations. Thus, a safe intensification process and selection of antidiabetic drugs with lower glycemic variability may achieve this goal. Recent developments in incretin-based therapies and longacting insulin analogs follow this principle, and demonstrate lower hypoglycemia risk than traditional therapies such as SU and human insulin. Some combination therapies have demonstrated desirable effects in middle-aged adults and thus may be appropriate for older patients. Future research is needed to explore the best combination of antidiabetic therapies for achieving glycemic control in elderly patients safely and effectively.

\section{Disclosure}

The authors report no conflicts of interest in this work.

\section{References}

1. International Diabetes Federation. IDF Diabetes Atlas. 6th ed. Brussels, Belgium: International Diabetes Federation; 2013.

2. Menz HB, Lord SR, St George R, Fitzpatrick RC. Walking stability and sensorimotor function in older people with diabetic peripheral neuropathy. Arch Phys Med Rehabil. 2004;85(2):245-252.

3. Roberts RO, Knopman DS, Przybelski SA, et al. Association of type 2 diabetes with brain atrophy and cognitive impairment. Neurology. 2014;82(13):1132-1141

4. Hasan SS, Mamun AA, Clavarino AM, Kairuz T. Incidence and risk of depression associated with diabetes in adults: evidence from longitudinal studies. Community Ment Health J. 2014. 
5. Chiu CJ, Wray LA, Beverly EA, Dominic OG. The role of health behaviors in mediating the relationship between depressive symptoms and glycemic control in type 2 diabetes: a structural equation modeling approach. Soc Psychiatry Psychiatr Epidemiol. 2010;45(1):67-76.

6. Chiu CJ, Wray LA. Gender differences in functional limitations in adults living with type 2 diabetes: biobehavioral and psychosocial mediators. Ann Behav Med. 2011;41(1):71-82.

7. Moghissi E. Management of type 2 diabetes mellitus in older patients: current and emerging treatment options. Diabetes Ther. 2013;4(2): 239-256.

8. Park SW, Goodpaster BH, Lee JS, et al; Health, Aging, and Body Composition Study. Excessive loss of skeletal muscle mass in older adults with type 2 diabetes. Diabetes Care. 2009;32(11):1993-1997.

9. Kim KS, Park KS, Kim MJ, Kim SK, Cho YW, Park SW. Type 2 diabetes is associated with low muscle mass in older adults. Geriatr Gerontol Int. 2014;14(suppl 1):115-121.

10. International Diabetes Federation. Managing Older People with Type 2 Diabetes. Brussels: IDF Global Guideline; 2013.

11. Ortiz-Alonso FJ, Galecki A, Herman WH, Smith MJ, Jacquez JA, Halter JB. Hypoglycemia counterregulation in elderly humans: relationship to glucose levels. Am J Physiol. 1994;267(4 pt 1):E497-E506.

12. Sinclair AJ, Paolisso G, Castro M, et al; European Diabetes Working Party for Older People. European diabetes working party for older people 2011 clinical guidelines for type 2 diabetes mellitus. Executive summary. Diabetes Metab. 2011;37(suppl 3):S27-S38.

13. Sinclair A, Morley JE, Rodriguez-Mañas L, et al. Diabetes mellitus in older people: position statement on behalf of the International Association of Gerontology and Geriatrics (IAGG), the European Diabetes Working Party for Older People (EDWPOP), and the International Task Force of Experts in Diabetes. $J$ Am Med Dir Assoc. 2012;13(6):497-502.

14. Sue Kirkman M, Briscoe VJ, Clark N, et al. Diabetes in older adults: a consensus report. J Am Geriatr Soc. 2012;60(12):2342-2356.

15. Canadian Diabetes Association Clinical Practice Guidelines Expert Committee, Meneilly GS, Knip A, Tessier D. Diabetes in the elderly. Can J Diabetes. 2013;37(suppl 1):S184-S190.

16. Mallery LH, Ransom T, Steeves B, Cook B, Dunbar P, Moorhouse P. Evidence-informed guidelines for treating frail older adults with type 2 diabetes: from the Diabetes Care Program of Nova Scotia (DCPNS) and the Palliative and Therapeutic Harmonization (PATH) program. J Am Med Dir Assoc. 2013;14(11):801-808.

17. Chen LK, Chen YM, Lin MH, Peng LN, Hwang SJ. Care of elderly patients with diabetes mellitus: a focus on frailty. Ageing Res Rev. 2010; 9(suppl 1):S18-S22.

18. Laubscher T, Regier L, Bareham J. Diabetes in the frail elderly: individualization of glycemic management. Can Fam Physician. 2012; 58(5):543-546.

19. Brown AF, Mangione CM, Saliba D, Sarkisian CA, California Healthcare Foundation/American Geriatrics Society Panel on Improving Care for Elders with Diabetes. Guidelines for improving the care of the older person with diabetes mellitus. J Am Geriatr Soc. 2003;51 (5 suppl Guidelines):S265-S280.

20. Pogach LM, Brietzke SA, Cowan CL Jr, et al; VA/DoD Diabetes Guideline Development Group. Development of evidence-based clinical practice guidelines for diabetes: the Department of Veterans Affairs/Department of Defense guidelines initiative. Diabetes Care. 2004;27(suppl 2):B82-B89.

21. VA/DoD Clinical Practice Guideline for the Management of Diabetes Mellitus. 2010; Available from: http://www.guideline.gov/content aspx?id=24192. Accessed May 17, 2014.

22. Abbatecola AM, Maggi S, Paolisso G. New approaches to treating type 2 diabetes mellitus in the elderly: role of incretin therapies. Drugs Aging. 2008;25(11):913-925.

23. Lachin JM, Orchard TJ, Nathan DM, Group DER. Update on cardiovascular outcomes at 30 years of the diabetes control and complications trial/epidemiology of diabetes interventions and complications study. Diabetes Care. 2014;37(1):39-43.
24. Holman RR, Paul SK, Bethel MA, Matthews DR, Neil HA. 10-year follow-up of intensive glucose control in type 2 diabetes. $N$ Engl J Med. 2008:359(15):1577-1589.

25. Duckworth W, Abraira C, Moritz T, et al. Glucose control and vascular complications in veterans with type 2 diabetes. $N$ Engl J Med. 2009; 360(2):129-139.

26. ADVANCE Collaborative Group; Patel A, MacMahon S, Chalmers J, et al. Intensive blood glucose control and vascular outcomes in patients with type 2 diabetes. N Engl J Med. 2008;358(24):2560-2572.

27. Action to Control Cardiovascular Risk in Diabetes Study Group, Gerstein HC, Miller ME, Byington RP, et al. Effects of intensive glucose lowering in type 2 diabetes. $N$ Engl J Med. 2008;358(24): 2545-2559.

28. Kim JH, Lim S, Choi SH, et al. Sarcopenia: an independent predictor of mortality in community-dwelling older Korean men. J Gerontol A Biol Sci Med Sci. 2014;69(10):1244-1252.

29. Cryer PE. Mechanisms of hypoglycemia-associated autonomic failure in diabetes. $N$ Engl J Med. 2013;369(4):362-372.

30. Bordier L, Doucet J, Boudet J, Bauduceau B. Update on cognitive decline and dementia in elderly patients with diabetes. Diabetes Metab. 2014.

31. Frier BM, Schernthaner G, Heller SR. Hypoglycemia and cardiovascular risks. Diabetes Care. 2011;34(suppl 2):S132-S137.

32. Schwartz AV, Margolis KL, Sellmeyer DE, et al. Intensive glycemic control is not associated with fractures or falls in the ACCORD randomized trial. Diabetes Care. 2012;35(7):1525-1531.

33. Puar TH, Khoo JJ, Cho LW, et al. Association between glycemic control and hip fracture. J Am Geriatr Soc. 2012;60(8):1493-1497.

34. Schwartz AV, Vittinghoff E, Sellmeyer DE, et al; Health, Aging, and Body Composition Study. Diabetes-related complications, glycemic control, and falls in older adults. Diabetes Care. 2008;31(3): 391-396.

35. Nelson JM, Dufraux K, Cook PF. The relationship between glycemic control and falls in older adults. J Am Geriatr Soc. 2007;55(12): 2041-2044.

36. Sinclair AJ, Task, Finish Group of Diabetes UK. Good clinical practice guidelines for care home residents with diabetes: an executive summary. Diabet Med. 2011;28(7):772-777.

37. Vischer UM, Perrenoud L, Genet C, Ardigo S, Registe-Rameau Y, Herrmann FR. The high prevalence of malnutrition in elderly diabetic patients: implications for anti-diabetic drug treatments. Diabet Med. 2010;27(8):918-924.

38. Canadian Diabetes Association Clinical Practice Guidelines Expert Committee; Imran SA, Rabasa-Lhoret R, Ross S. Targets for glycemic control. Can J Diabetes. 2013;37(suppl 1):S31-S34.

39. Rosenstock J. Management of type 2 diabetes mellitus in the elderly: special considerations. Drugs Aging. 2001;18(1):31-44.

40. Yaffe K, Falvey C, Hamilton N, et al. Diabetes, glucose control, and 9-year cognitive decline among older adults without dementia. Arch Neurol. 2012;69(9):1170-1175.

41. Sinclair A, Morley JE. How to manage diabetes mellitus in older persons in the 21st century: applying these principles to long term diabetes care. J Am Med Dir Assoc. 2013;14(11):777-780.

42. Mooradian AD, Morley JE. Micronutrient status in diabetes mellitus. Am J Clin Nutr. 1987;45(5):877-895.

43. Gaglia JL, Wyckoff J, Abrahamson MJ. Acute hyperglycemic crisis in the elderly. Med Clin North Am. 2004;88(4):1063-1084; xii.

44. Chiu CJ, Wray LA, Ofstedal MB. Diabetes-related change in physical disability from midlife to older adulthood: evidence from 1996-2003 Survey of Health and Living Status of the Elderly in Taiwan. Diabetes Res Clin Pract. 2011;91(3):413-423.

45. Chiu CJ, Wray LA. Physical disability trajectories in older Americans with and without diabetes: the role of age, gender, race or ethnicity, and education. Gerontologist. 2011;51(1):51-63.

46. Rizzo MR, Marfella R, Barbieri M, et al. Relationships between daily acute glucose fluctuations and cognitive performance among aged type 2 diabetic patients. Diabetes Care. 2010;33(10):2169-2174. 
47. Rizzo MR, Barbieri M, Marfella R, Paolisso G. Reduction of oxidative stress and inflammation by blunting daily acute glucose fluctuations in patients with type 2 diabetes: role of dipeptidyl peptidase-IV inhibition. Diabetes Care. 2012;35(10):2076-2082.

48. Wang CP, Hazuda HP. Better glycemic control is associated with maintenance of lower-extremity function over time in Mexican American and European American older adults with diabetes. Diabetes Care. 2011;34(2):268-273.

49. Teoh H, Home P, Leiter LA. Should A1C targets be individualized for all people with diabetes? Arguments for and against. Diabetes Care. 2011;34(supp1 2):S191-S196.

50. Munshi MN, Segal AR, Suhl E, et al. Frequent hypoglycemia among elderly patients with poor glycemic control. Arch Intern Med. 2011; 171(4):362-364

51. Mori Y. [Exploring an optimal approach to the use of oral hypoglycemic agents based on CGM results: implications for combination therapy with oral hypoglycemic agents]. Nihon Rinsho. 2011;69(8): $1505-1514$

52. McLaren LA, Quinn TJ, McKay GA. Diabetes control in older people. BMJ. 2013;346:f2625.

53. Meneilly GS, Ryan AS, Veldhuis JD, Elahi D. Increased disorderliness of basal insulin release, attenuated insulin secretory burst mass, and reduced ultradian rhythmicity of insulin secretion in older individuals. J Clin Endocrinol Metab. 1997;82(12):4088-4093.

54. Geloneze B, de Oliveira MD, Vasques AC, Novaes FS, Pareja JC, Tambascia MA. Impaired incretin secretion and pancreatic dysfunction with older age and diabetes. Metabolism. 2014;63(7):922-929.

55. Munshi MN, Pandya N, Umpierrez GE, DiGenio A, Zhou R, Riddle MC. Contributions of basal and prandial hyperglycemia to total hyperglycemia in older and younger adults with type 2 diabetes mellitus. J Am Geriatr Soc. 2013;61(4):535-541.

56. Huang ES, Laiteerapong N, Liu JY, John PM, Moffet HH, Karter AJ. Rates of complications and mortality in older patients with diabetes mellitus: the diabetes and aging study. JAMA Intern Med. 2014; 174(2):251-258

57. Shorr RI, Ray WA, Daugherty JR, Griffin MR. Incidence and risk factors for serious hypoglycemia in older persons using insulin or sulfonylureas. Arch Intern Med. 1997;157(15):1681-1686.

58. Bremer JP, Jauch-Chara K, Hallschmid M, Schmid S, Schultes B. Hypoglycemia unawareness in older compared with middle-aged patients with type 2 diabetes. Diabetes Care. 2009;32(8):1513-1517.

59. Abdelhafiz AH, Bailey C, Eng Loo B, Sinclair A. Hypoglycaemic symptoms and hypoglycaemia threshold in older people with diabetes a patient perspective. J Nutr Health Aging. 2013;17(10):899-902.

60. Meneilly GS, Cheung E, Tuokko H. Altered responses to hypoglycemia of healthy elderly people. J Clin Endocrinol Metab. 1994;78(6): 1341-1348.

61. DRUGDEX ${ }^{\circledR}$ System. Greenwood Village, CO: Thomson Healthcare; 2011; Updated periodically.

62. Lexi-Drugs Online. Hudson, OH: Lexi-Comp, Inc [Updated September 13, 2014].

63. Chiu CJ, Wray LA. Factors predicting glycemic control in middleaged and older adults with type 2 diabetes. Prev Chronic Dis. 2010; 7(1):A08.

64. Chiu CJ, Wray LA, Lu FH, Beverly EA. BMI change patterns and disability development of middle-aged adults with diabetes: a dual trajectory modeling approach. J Gen Intern Med. 2013;28(9): $1150-1156$.

65. Chiu CJ, Wray LA, Beverly EA. Relationship of glucose regulation to changes in weight: a systematic review and guide to future research. Diabetes Metab Res Rev. 2010;26(5):323-335.

66. Bauer J, Biolo G, Cederholm T, et al. Evidence-based recommendations for optimal dietary protein intake in older people: a position paper from the PROT-AGE Study Group. J Am Med Dir Assoc. 2013; 14(8):542-559.
67. Daly RM, O'Connell SL, Mundell NL, Grimes CA, Dunstan DW, Nowson CA. Protein-enriched diet, with the use of lean red meat, combined with progressive resistance training enhances lean tissue mass and muscle strength and reduces circulating IL-6 concentrations in elderly women: a cluster randomized controlled trial. Am J Clin Nutr. 2014;99(4):899-910.

68. Morrison S, Colberg SR, Parson HK, Vinik AI. Exercise improves gait, reaction time and postural stability in older adults with type 2 diabetes and neuropathy. J Diabetes Complications. 2014;28(5):715-722.

69. Lee CG, Boyko EJ, Barrett-Connor E, et al; Osteoporotic Fractures in Men (MrOS) Study Research Group. Insulin sensitizers may attenuate lean mass loss in older men with diabetes. Diabetes Care. 2011;34(11):2381-2386.

70. Soe K, Sacerdote A, Karam J, Bahtiyar G. Management of type 2 diabetes mellitus in the elderly. Maturitas. 2011;70(2):151-159.

71. Neumiller JJ, Setter SM. Pharmacologic management of the older patient with type 2 diabetes mellitus. Am J Geriatr Pharmacother. 2009;7(6): 324-342.

72. Almirall J, Briculle M, Gonzalez-Clemente JM. Metforminassociated lactic acidosis in type 2 diabetes mellitus: incidence and presentation in common clinical practice. Nephrol Dial Transplant. 2008;23(7):2436-2438.

73. Rachmani R, Slavachevski I, Levi Z, Zadok B, Kedar Y, Ravid M. Metformin in patients with type 2 diabetes mellitus: reconsideration of traditional contraindications. Eur J Intern Med. 2002;13(7):428.

74. Tahrani AA, Varughese GI, Scarpello JH, Hanna FW. Metformin, heart failure, and lactic acidosis: is metformin absolutely contraindicated? BMJ. 2007;335(7618):508-512.

75. Eppenga WL, Lalmohamed A, Geerts AF, et al. Risk of lactic acidosis or elevated lactate concentrations in metformin users with renal impairment: a population-based cohort study. Diabetes Care. 2014; 37(8):2218-2224.

76. Zhang X, Harmsen WS, Mettler TA, et al. Continuation of metformin use after a diagnosis of cirrhosis significantly improves survival of patients with diabetes. Hepatology. 2014

77. Salpeter SR, Greyber E, Pasternak GA, Salpeter EE. Risk of fatal and nonfatal lactic acidosis with metformin use in type 2 diabetes mellitus. Cochrane Database Syst Rev. 2010(4):CD002967.

78. Holstein A, Stumvoll M. Contraindications can damage your health - is metformin a case in point? Diabetologia. 2005;48(12):2454-2459.

79. Lin YC, Lin LY, Wang HF, Lin HD. Fasting plasma lactate concentrations in ambulatory elderly patients with type 2 diabetes receiving metformin therapy: a retrospective cross-sectional study. $J$ Chin Med Assoc. 2010;73(12):617-622.

80. McCormack J, Johns K, Tildesley H. Metformin's contraindications should be contraindicated. Can Med Assoc J. 2005;173(5):502-504.

81. Kos E, Liszek MJ, Emanuele MA, Durazo-Arvizu R, Camacho P. Effect of metformin therapy on vitamin $\mathrm{D}$ and vitamin $\mathrm{B}(1)(2)$ levels in patients with type 2 diabetes mellitus. Endocr Pract. 2012;18(2):179-184.

82. de Jager J, Kooy A, Lehert P, et al. Long term treatment with metformin in patients with type 2 diabetes and risk of vitamin B-12 deficiency: randomised placebo controlled trial. BMJ. 2010;340:c2181.

83. Inzucchi SE, Bergenstal RM, Buse JB, et al. Management of hyperglycemia in type 2 diabetes: a patient-centered approach: position statement of the American Diabetes Association (ADA) and the European Association for the Study of Diabetes (EASD). Diabetes Care. 2012;35(6):1364-1379.

84. Rajagopalan R, Perez A, Ye Z, Khan M, Murray FT. Pioglitazone is effective therapy for elderly patients with type 2 diabetes mellitus. Drugs Aging. 2004;21(4):259-271.

85. Alba M, Ahrén B, Inzucchi SE, et al. Sitagliptin and pioglitazone provide complementary effects on postprandial gPioglitazone is effective therapy for elderly patients with type 2 diabetes mellituslucose and pancreatic islet cell function. Diabetes Obes Metab. 2013;15(12):1101-1110. 
86. Kung J, Henry RR. Thiazolidinedione safety. Expert Opin Drug Saf. 2012;11(4):565-579.

87. Rajagopalan R, Xu Y, Abbadessa M, Quartet Study G. The effect of pioglitazone on glycemic and lipid parameters and adverse events in elderly patients with type 2 diabetes mellitus: a post hoc analysis of four randomized trials. Am J Geriatr Pharmacother. 2006;4(2):123-133.

88. Kahn SE, Haffner SM, Heise MA, et al; ADOPT Study Group. Glycemic durability of rosiglitazone, metformin, or glyburide monotherapy. N Engl J Med. 2006;355(23):2427-2443.

89. Kahn SE, Zinman B, Lachin JM, et al; Diabetes Outcome Progression Trial (ADOPT) Study Group. Rosiglitazone-associated fractures in type 2 diabetes: an Analysis from A Diabetes Outcome Progression Trial (ADOPT). Diabetes Care. 2008;31(5):845-851.

90. Dormandy J, Bhattacharya M, van Troostenburg de Bruyn AR, PROactive Investigators. Safety and tolerability of pioglitazone in high-risk patients with type 2 diabetes: an overview of data from PROactive. Drug Saf. 2009;32(3):187-202.

91. Grey A, Bolland M, Fenwick S, et al. The skeletal effects of pioglitazone in type 2 diabetes or impaired glucose tolerance: a randomized controlled trial. Eur J Endocrinol. 2014;170(2):255-262.

92. Bone HG, Lindsay R, McClung MR, Perez AT, Raanan MG, Spanheimer RG. Effects of pioglitazone on bone in postmenopausal women with impaired fasting glucose or impaired glucose tolerance: a randomized, double-blind, placebo-controlled study. J Clin Endocrinol Metab. 2013;98(12):4691-4701.

93. Habib ZA, Havstad SL, Wells K, Divine G, Pladevall M, Williams LK. Thiazolidinedione use and the longitudinal risk of fractures in patients with type 2 diabetes mellitus. $J$ Clin Endocrinol Metab. 2010;95(2):592-600.

94. Grey A. Thiazolidinedione-induced skeletal fragility - mechanisms and implications. Diabetes Obes Metab. 2009;11(4):275-284.

95. Seaquist ER, Miller ME, Fonseca V, et al. Effect of thiazolidinediones and insulin on cognitive outcomes in ACCORD-MIND. $J$ Diabetes Complications. 2013;27(5):485-491.

96. Miller BW, Willett KC, Desilets AR. Rosiglitazone and pioglitazone for the treatment of Alzheimer's disease. Ann Pharmacother. 2011; 45(11):1416-1424.

97. Sato T, Hanyu H, Hirao K, Kanetaka H, Sakurai H, Iwamoto T. Efficacy of PPAR-gamma agonist pioglitazone in mild Alzheimer disease. Neurobiol Aging. 2011;32(9):1626-1633.

98. Read S, Wu P, Biscow M. Sustained 4-year cognitive and functional response in early Alzheimer's disease with pioglitazone. $J$ Am Geriatr Soc. 2014;62(3):584-586.

99. Hoshikawa Y, Ohkoshi K. [Association between pioglitazone and diabetic macular edema]. Nippon Ganka Gakkai zasshi. 2013;117(4): 357-363.

100. Azar S, El-Mollayess GM, Al Shaar L, Salti HI, Bashshur ZF. Impact of thiazolidinediones on macular thickness and volume in diabetic eyes. Can J Ophthalmol. 2013;48(4):312-316.

101. Home PD, Pocock SJ, Beck-Nielsen H, et al; RECORD Study Team. Rosiglitazone evaluated for cardiovascular outcomes in oral agent combination therapy for type 2 diabetes (RECORD): a multicentre, randomised, open-label trial. Lancet. 2009;373(9681):2125-2135.

102. Hernandez AV, Usmani A, Rajamanickam A, Moheet A. Thiazolidinediones and risk of heart failure in patients with or at high risk of type 2 diabetes mellitus: a meta-analysis and meta-regression analysis of placebo-controlled randomized clinical trials. $\mathrm{Am} \mathrm{J}$ Cardiovasc Drugs. 2011;11(2):115-128.

103. Viswanathan V, Mohan V, Subramani P, et al. Effect of spironolactone and amiloride on thiazolidinedione-induced fluid retention in South Indian patients with type 2 diabetes. Clin J Am Soc Nephrol. 2013;8(2):225-232.

104. Nissen SE, Wolski K. Effect of rosiglitazone on the risk of myocardial infarction and death from cardiovascular causes. $N$ Engl J Med. 2007;356(24):2457-2471.
105. Dormandy JA, Charbonnel B, Eckland DJ, et al. Secondary prevention of macrovascular events in patients with type 2 diabetes in the PROactive Study (PROspective pioglitAzone Clinical Trial In macroVascular Events): a randomised controlled trial. Lancet. 2005;366(9493):1279-1289.

106. Lu CJ, Sun Y, Muo CH, Chen RC, Chen PC, Hsu CY. Risk of stroke with thiazolidinediones: a ten-year nationwide population-based cohort study. Cerebrovasc Dis. 2013;36(2):145-151.

107. Vallarino C, Perez A, Fusco G, et al. Comparing pioglitazone to insulin with respect to cancer, cardiovascular and bone fracture endpoints, using propensity score weights. Clin Drug Investig. 2013;33(9): $621-631$

108. Mahaffey KW, Hafley G, Dickerson S, et al. Results of a reevaluation of cardiovascular outcomes in the RECORD trial. Am Heart $J$. 2013;166(2):240-249; 241.

109. Fu H, Xie W, Curtis B, Schuster D. Identifying factors associated with hypoglycemia-related hospitalizations among elderly patients with T2DM in the US: a novel approach using influential variable analysis. Curr Med Res Opin. 2014;29:1-7.

110. van Staa T, Abenhaim L, Monette J. Rates of hypoglycemia in users of sulfonylureas. J Clin Epidemiol. 1997;50(6):735-741.

111. Chelliah A, Burge MR. Hypoglycaemia in elderly patients with diabetes mellitus: causes and strategies for prevention. Drugs Aging. 2004;21(8):511-530.

112. Kim MK, Suk JH, Kwon MJ, et al. Nateglinide and acarbose for postprandial glucose control after optimizing fasting glucose with insulin glargine in patients with type 2 diabetes. Diabetes Res Clin Pract. 2011;92(3):322-328.

113. Papa G, Fedele V, Rizzo MR, et al. Safety of type 2 diabetes treatment with repaglinide compared with glibenclamide in elderly people: a randomized, open-label, two-period, cross-over trial. Diabetes Care. 2006;29(8):1918-1920.

114. Wang JS, Lin SD, Lee WJ, et al. Effects of acarbose versus glibenclamide on glycemic excursion and oxidative stress in type 2 diabetic patients inadequately controlled by metformin: a 24-week, randomized, open-label, parallel-group comparison. Clin Ther. 2011;33(12):1932-1942.

115. Enç FY, Imeryüz N, Akin L, et al. Inhibition of gastric emptying by acarbose is correlated with GLP-1 response and accompanied by CCK release. Am J Physiol Gastrointest Liver Physiol. 2001; 281(3):G752-G763.

116. DeLeon MJ, Chandurkar V, Albert SG, Mooradian AD. Glucagonlike peptide-1 response to acarbose in elderly type 2 diabetic subjects. Diabetes Res Clin Pract. 2002;56(2):101-106.

117. Meneilly GS, Ryan EA, Radziuk J, et al. Effect of acarbose on insulin sensitivity in elderly patients with diabetes. Diabetes Care. 2000;23(8):1162-1167.

118. Sangiorgio L, Attardo T, Condorelli L, Lunetta M. Effects of the treatment with acarbose in elderly overweight type 2 diabetic patients in poor glycemic control with oral hypoglycemic agents or insulin. Arch Gerontol Geriatr. 2000;31(1):27-34.

119. Hsieh CJ. Acarbose reduces the risk of pre-lunch hypoglycemia in elderly people with diabetes eating rice porridge for breakfast. Diabetes Res Clin Pract. 2010;89(3):e66-e68.

120. Li C, Hung YJ, Qamruddin K, Aziz MF, Stein H, Schmidt B. International noninterventional study of acarbose treatment in patients with type 2 diabetes mellitus. Diabetes Res Clin Pract. 2011;92(1):57-64.

121. Spengler M, Schmitz H, Landen H. Evaluation of the efficacy and tolerability of acarbose in patients with diabetes mellitus: a postmarketing surveillance study. Clin Drug Investig. 2005; 25(10):651-659

122. Mertes G. Safety and efficacy of acarbose in the treatment of type 2 diabetes: data from a 5-year surveillance study. Diabetes Res Clin Pract. 2001;52(3):193-204. 
123. Buse J, Hart K, Minasi L. The PROTECT Study: final results of a large multicenter postmarketing study in patients with type 2 diabetes. Precose Resolution of Optimal Titration to Enhance Current Therapies. Clin Ther. 1998;20(2):257-269.

124. Germino FW. Noninsulin treatment of type 2 diabetes mellitus in geriatric patients: a review. Clin Ther. 2011;33(12):1868-1882.

125. Karyekar CS, Ravichandran S, Allen E, Fleming D, Frederich R. Tolerability and efficacy of glycemic control with saxagliptin in older patients (aged $\geq 65$ years) with inadequately controlled type 2 diabetes mellitus. Clin Interv Aging. 2013;8:419-430.

126. Strain WD, Lukashevich V, Kothny W, Hoellinger MJ, Paldanius PM. Individualised treatment targets for elderly patients with type 2 diabetes using vildagliptin add-on or lone therapy (INTERVAL): a 24 week, randomised, double-blind, placebo-controlled study. Lancet. 2013;382(9890):409-416.

127. Schweizer A, Dejager S, Bosi E. Comparison of vildagliptin and metformin monotherapy in elderly patients with type 2 diabetes: a 24-week, double-blind, randomized trial. Diabetes Obes Metab. 2009;11(8):804-812.

128. Schweizer A, Dejager S, Foley JE, Shao Q, Kothny W. Clinical experience with vildagliptin in the management of type 2 diabetes in a patient population $\geq 75$ years: a pooled analysis from a database of clinical trials. Diabetes Obes Metab. 2011;13(1):55-64.

129. Barnett AH, Huisman H, Jones R, von Eynatten M, Patel S, Woerle HJ. Linagliptin for patients aged 70 years or older with type 2 diabetes inadequately controlled with common antidiabetes treatments: a randomised, double-blind, placebo-controlled trial. Lancet. 2013;382(9902):1413-1423.

130. Barzilai N, Guo H, Mahoney EM, et al. Efficacy and tolerability of sitagliptin monotherapy in elderly patients with type 2 diabetes: a randomized, double-blind, placebo-controlled trial. Curr Med Res Opin. 2011;27(5):1049-1058.

131. Giorda CB, Nada E, Tartaglino B. Pharmacokinetics, safety, and efficacy of DPP-4 inhibitors and GLP-1 receptor agonists in patients with type 2 diabetes mellitus and renal or hepatic impairment. A systematic review of the literature. Endocrine. 2014;46(3):406-419.

132. Drucker DJ, Nauck MA. The incretin system: glucagon-like peptide-1 receptor agonists and dipeptidyl peptidase- 4 inhibitors in type 2 diabetes. Lancet. 2006;368(9548):1696-1705.

133. Rosenstock J, Wilson C, Fleck P. Alogliptin versus glipizide monotherapy in elderly type 2 diabetes mellitus patients with mild hyperglycaemia: a prospective, double-blind, randomized, 1-year study. Diabetes Obes Metab. 2013;15(10):906-914.

134. Ando Y. [Treatment strategy for elderly diabetic patient with insulin or GLP-1 receptor agonist]. Nihon Rinsho. 2013;71(11):1993-1998.

135. Bode BW, Brett J, Falahati A, Pratley RE. Comparison of the efficacy and tolerability profile of liraglutide, a once-daily human GLP-1 analog, in patients with type 2 diabetes $\geq 65$ and $<65$ years of age: a pooled analysis from phase III studies. Am J Geriatr Pharmacother. 2011;9(6):423-433.

136. Linnebjerg H, Kothare PA, Seger M, Wolka AM, Mitchell MI. Exenatide - pharmacokinetics, pharmacodynamics, safety and tolerability in patients $\geq 75$ years of age with type 2 diabetes. Int J Clin Pharmacol Ther. 2011;49(2):99-108.

137. Suzuki D, Toyoda M, Kimura M, et al. Effects of liraglutide, a human glucagon-like peptide-1 analogue, on body weight, body fat area and body fat-related markers in patients with type 2 diabetes mellitus. Intern Med. 2013;52(10):1029-1034.

138. Fan H, Pan Q, Xu Y, Yang X. Exenatide improves type 2 diabetes concomitant with non-alcoholic fatty liver disease. Arq Bras Endocrinol Metabol. 2013;57(9):702-708.

139. Ponzani P. Long-term effectiveness and safety of liraglutide in clinical practice. Minerva Endocrinol. 2013;38(1):103-112.

140. Pawaskar M, Li Q, Reynolds MW. Metabolic outcomes of elderly patient populations initiating exenatide BID versus insulin glargine in an ambulatory care setting. Curr Med Res Opin . 2012;28(6):991-997.
141. Jacobsen LV, Hindsberger C, Robson R, Zdravkovic M. Effect of renal impairment on the pharmacokinetics of the GLP-1 analogue liraglutide. Br J Clin Pharmacol. 2009;68(6):898-905.

142. Malm-Erjefält M, Bjørnsdottir I, Vanggaard J, et al. Metabolism and excretion of the once-daily human glucagon-like peptide-1 analog liraglutide in healthy male subjects and its in vitro degradation by dipeptidyl peptidase IV and neutral endopeptidase. Drug Metab Dispos. 2010;38(11):1944-1953.

143. Davidson JA, Brett J, Falahati A, Scott D. Mild renal impairment and the efficacy and safety of liraglutide. Endocr Pract. 2011; 17(3):345-355.

144. National Cholesterol Education Program Expert Panel on Detection, Evaluation, and Treatment of High Blood Cholesterol in Adults (Adult Treatment Panel III). Third Report of the National Cholesterol Education Program (NCEP) Expert Panel on Detection, Evaluation, and Treatment of High Blood Cholesterol in Adults (Adult Treatment Panel III) final report. Circulation. 2002;106(25):3143-3421.

145. Bays HE, Goldberg RB, Truitt KE, Jones MR. Colesevelam hydrochloride therapy in patients with type 2 diabetes mellitus treated with metformin: glucose and lipid effects. Arch Intern Med. 2008;168(18):1975-1983.

146. Fonseca VA, Rosenstock J, Wang AC, Truitt KE, Jones MR. Colesevelam $\mathrm{HCl}$ improves glycemic control and reduces LDL cholesterol in patients with inadequately controlled type 2 diabetes on sulfonylureabased therapy. Diabetes Care. 2008;31(8):1479-1484.

147. Goldberg RB, Fonseca VA, Truitt KE, Jones MR. Efficacy and safety of colesevelam in patients with type 2 diabetes mellitus and inadequate glycemic control receiving insulin-based therapy. Arch Intern Med. 2008;168(14):1531-1540.

148. Bays $\mathrm{H}$, Dujovne C. Colesevelam $\mathrm{HCl}$ : a non-systemic lipid-altering drug. Expert Opin Pharmacother. 2003;4(5):779-790.

149. Rosenbaum DP, Petersen JS, Ducharme S, Markham P, Goldberg DI. Absorption, distribution and excretion of GT31-104, a novel bile acid sequestrant, in rats and dogs after acute and subchronic administration. J Pharm Sci. 1997;86(5):591-595.

150. Ooi CP, Loke SC. Colesevelam for type 2 diabetes mellitus. Cochrane Database Syst Rev. 2012;12:CD009361.

151. Gavin JR 3rd, Jones MR, Ford DM, Truitt KE. Safety and efficacy of Colesevelam $\mathrm{HCl}$ in the treatment of elderly patients. Drugs Aging. 2014;31(6):461-470.

152. Garber AJ, Abrahamson MJ, Barzilay JI, et al. AACE comprehensive diabetes management algorithm 2013. Endocr Pract. 2013; 19(2):327-336.

153. Clar C, Gill JA, Court R, Waugh N. Systematic review of SGLT2 receptor inhibitors in dual or triple therapy in type 2 diabetes. $B M J$ Open. 2012;2(5):ii:e001007.

154. Davis CS, Fleming JW, Warrington LE. Sodium glucose co-transporter 2 inhibitors: a novel approach to the management of type 2 diabetes mellitus. J Am Assoc Nurse Pract. 2014;26(7):356-363.

155. Bolinder J, Ljunggren Ö, Kullberg J, et al. Effects of dapagliflozin on body weight, total fat mass, and regional adipose tissue distribution in patients with type 2 diabetes mellitus with inadequate glycemic control on metformin. J Clin Endocrinol Metab. 2012;97(3):1020-1031.

156. Bailey CJ, Gross JL, Pieters A, Bastien A, List JF. Effect of dapagliflozin in patients with type 2 diabetes who have inadequate glycaemic control with metformin: a randomised, double-blind, placebo-controlled trial. Lancet. 2010;375(9733):2223-2233.

157. Riser Taylor S, Harris KB. The clinical efficacy and safety of sodium glucose cotransporter-2 inhibitors in adults with type 2 diabetes mellitus. Pharmacotherapy. 2013;33(9):984-999.

158. Kasichayanula S, Chang M, Hasegawa M, et al. Pharmacokinetics and pharmacodynamics of dapagliflozin, a novel selective inhibitor of sodium-glucose co-transporter type 2, in Japanese subjects without and with type 2 diabetes mellitus. Diabetes Obes Metab. 2011;13(4):357-365. 
159. Kasichayanula S, Liu X, Shyu WC, et al. Lack of pharmacokinetic interaction between dapagliflozin, a novel sodium-glucose transporter 2 inhibitor, and metformin, pioglitazone, glimepiride or sitagliptin in healthy subjects. Diabetes Obes Metab. 2011;13(1):47-54.

160. Komoroski B, Vachharajani N, Feng Y, Li L, Kornhauser D, Pfister M. Dapagliflozin, a novel, selective SGLT2 inhibitor, improved glycemic control over 2 weeks in patients with type 2 diabetes mellitus. Clin Pharmacol Ther. 2009;85(5):513-519.

161. Stenlöf K, Cefalu WT, Kim KA, et al. Efficacy and safety of canagliflozin monotherapy in subjects with type 2 diabetes mellitus inadequately controlled with diet and exercise. Diabetes Obes Metab. 2013;15(4):372-382.

162. Ferrannini E, Ramos SJ, Salsali A, Tang W, List JF. Dapagliflozin monotherapy in type 2 diabetic patients with inadequate glycemic control by diet and exercise: a randomized, double-blind, placebo-controlled, phase 3 trial. Diabetes Care. 2010;33(10): 2217-2224

163. Strojek K, Yoon KH, Hruba V, Elze M, Langkilde AM, Parikh S. Effect of dapagliflozin in patients with type 2 diabetes who have inadequate glycaemic control with glimepiride: a randomized, 24-week, double-blind, placebo-controlled trial. Diabetes Obes Metab. 2011;13(10):928-938.

164. Wilding JP, Woo V, Soler NG, et al; Dapagliflozin 006 Study Group. Long-term efficacy of dapagliflozin in patients with type 2 diabetes mellitus receiving high doses of insulin: a randomized trial. Ann Intern Med. 2012;156(6):405-415.

165. Bailey CJ, Gross JL, Hennicken D, Iqbal N, Mansfield TA, List JF. Dapagliflozin add-on to metformin in type 2 diabetes inadequately controlled with metformin: a randomized, double-blind, placebocontrolled 102-week trial. BMC Med. 2013;11:43.

166. Elmore LK, Baggett S, Kyle JA, Skelley JW. A review of the efficacy and safety of canagliflozin in elderly patients with type 2 diabetes. Consult Pharm. 2014;29(5):335-346.

167. Chen K-W, Tseng H-M, Huang Y-Y, Chuang Y-J. The barriers to initiating insulin therapy among people with type 2 diabetes in Taiwan - a qualitative study. J Diabetes Metab. 2012;3(5):194.

168. Rosenstock J, Schwartz SL, Clark CM Jr, Park GD, Donley DW, Edwards MB. Basal insulin therapy in type 2 diabetes: 28-week comparison of insulin glargine (HOE 901) and NPH insulin. Diabetes Care. 2001;24(4):631-636.

169. Sorli C, Warren M, Oyer D, Mersebach H, Johansen T, Gough SC Elderly patients with diabetes experience a lower rate of nocturnal hypoglycaemia with insulin degludec than with insulin glargine: a meta-analysis of phase IIIa trials. Drugs Aging. 2013;30(12) 1009-1018.

170. Lee P, Chang A, Blaum C, Vlajnic A, Gao L, Halter J. Comparison of safety and efficacy of insulin glargine and neutral protamine hagedorn insulin in older adults with type 2 diabetes mellitus: results from a pooled analysis. J Am Geriatr Soc. 2012;60(1):51-59.

171. Philis-Tsimikas A, Charpentier G, Clauson P, Ravn GM, Roberts VL, Thorsteinsson B. Comparison of once-daily insulin detemir with $\mathrm{NPH}$ insulin added to a regimen of oral antidiabetic drugs in poorly controlled type 2 diabetes. Clin Ther. 2006;28(10):1569-1581.

172. Horvath K, Jeitler K, Berghold A, et al. Long-acting insulin analogues versus NPH insulin (human isophane insulin) for type 2 diabetes mellitus. Cochrane Database Syst Rev. 2007;2:CD005613.

173. Brunton S. Initiating insulin therapy in type 2 diabetes: benefits of insulin analogs and insulin pens. Diabetes Technol Ther. 2008;10(4):247-256.

174. Coscelli C, Lostia S, Lunetta M, Nosari I, Coronel GA. Safety, efficacy, acceptability of a pre-filled insulin pen in diabetic patients over 60 years old. Diabetes Res Clin Pract. 1995;28(3):173-177.

175. Papa G, Fedele V, Chiavetta A, et al. Therapeutic options for elderly diabetic subjects: open label, randomized clinical trial of insulin glargine added to oral antidiabetic drugs versus increased dosage of oral antidiabetic drugs. Acta Diabetol. 2008;45(1):53-59.
176. Mooradian AD, Osterweil D, Petrasek D, Morley JE. Diabetes mellitus in elderly nursing home patients. A survey of clinical characteristics and management. J Am Geriatr Soc. 1988;36(5):391-396.

177. Gomez-Peralta F, Carraminana-Barrera F, Felix-Redondo FJ, Fraile-Gomez J, Extreme Rescue Study Group. Glycaemic control in patients with type 2 diabetes switching from premixed insulin to long-acting basal insulin analogue plus oral antidiabetic drugs: an observational study. Int J Clin Pract. 2012;66(10):959-968.

178. Reza M, Taylor CD, Towse K, Ward JD, Hendra TJ. Insulin improves well-being for selected elderly type 2 diabetic subjects. Diabetes Res Clin Pract. 2002;55(3):201-207.

179. Sicras-Mainar A, Navarro-Artieda R. Use of metformin and vildagliptin for treatment of type 2 diabetes in the elderly. Drug Des Devel Ther. 2014;8:811-818

180. Ferrannini E, Fonseca V, Zinman B, et al. Fifty-two-week efficacy and safety of vildagliptin vs glimepiride in patients with type 2 diabetes mellitus inadequately controlled on metformin monotherapy. Diabetes Obes Metab. 2009;11(2):157-166.

181. Matthews DR, Dejager S, Ahren B, et al. Vildagliptin add-on to metformin produces similar efficacy and reduced hypoglycaemic risk compared with glimepiride, with no weight gain: results from a 2-year study. Diabetes Obes Metab. 2010;12(9):780-789.

182. Filozof C, Gautier JF. A comparison of efficacy and safety of vildagliptin and gliclazide in combination with metformin in patients with Type 2 diabetes inadequately controlled with metformin alone: a 52-week, randomized study. Diabet Med. 2010;27(3):318-326.

183. Göke B, Gallwitz B, Eriksson J, Hellqvist A, Gause-Nilsson I; D1680C00001 Investigators. Saxagliptin is non-inferior to glipizide in patients with type 2 diabetes mellitus inadequately controlled on metformin alone: a 52-week randomised controlled trial. Int J Clin Pract. 2010;64(12):1619-1631.

184. Gallwitz B, Rosenstock J, Rauch T, et al. 2-year efficacy and safety of linagliptin compared with glimepiride in patients with type 2 diabetes inadequately controlled on metformin: a randomised, double-blind, non-inferiority trial. Lancet. 2012;380(9840):475-483.

185. Aschner P, Chan J, Owens DR, et al; EASIE Investigators. Insulin glargine versus sitagliptin in insulin-naive patients with type 2 diabetes mellitus uncontrolled on metformin (EASIE): a multicentre, randomised open-label trial. Lancet. 2012;379(9833):2262-2269.

186. Nauck MA, Meininger G, Sheng D, Terranella L, Stein PP, Sitagliptin Study G. Efficacy and safety of the dipeptidyl peptidase-4 inhibitor, sitagliptin, compared with the sulfonylurea, glipizide, in patients with type 2 diabetes inadequately controlled on metformin alone: a randomized, double-blind, non-inferiority trial. Diabetes Obes Metab. 2007;9(2):194-205.

187. Ahrén B, Foley JE, Ferrannini E, et al. Changes in prandial glucagon levels after a 2-year treatment with vildagliptin or glimepiride in patients with type 2 diabetes inadequately controlled with metformin monotherapy. Diabetes Care. 2010;33(4):730-732.

188. Forst T, Dworak M, Berndt-Zipfel C, et al. Effect of vildagliptin compared to glimepiride on postprandial proinsulin processing in the beta cell of patients with type 2 diabetes mellitus. Diabetes Obes Metab. 2013;15(6):576-579.

189. He YL, Foteinos G, Neelakantham S, et al. Differential effects of vildagliptin and glimepiride on glucose fluctuations in patients with type 2 diabetes mellitus assessed using continuous glucose monitoring. Diabetes Obes Metab. 2013;15(12):1111-1119.

190. Guerci B, Monnier L, Serusclat P, et al. Continuous glucose profiles with vildagliptin versus sitagliptin in add-on to metformin results from the randomized Optima study. Diabetes Metab. 2012;38(4):359-366.

191. Viriato D, Calado F, Gruenberger JB, et al. Cost-effectiveness of metformin plus vildagliptin compared with metformin plus sulphonylurea for the treatment of patients with type 2 diabetes mellitus: a Portuguese healthcare system perspective. J Med Econ. 2014;17(7):499-507. 
192. Granstrom O, Bergenheim K, McEwan P, Sennfalt K, Henriksson M. Cost-effectiveness of saxagliptin (Onglyza(R)) in type 2 diabetes in Sweden. Prim Care Diabetes. 2012;6(2):127-136.

193. Takihata M, Nakamura A, Tajima K, et al. Comparative study of sitagliptin with pioglitazone in Japanese type 2 diabetic patients: the COMPASS randomized controlled trial. Diabetes Obes Metab. 2013;15(5):455-462.

194. Bolli G, Dotta F, Rochotte E, Cohen SE. Efficacy and tolerability of vildagliptin vs pioglitazone when added to metformin: a 24-week, randomized, double-blind study. Diabetes Obes Metab. 2008;10(1):82-90.

195. Bolli G, Dotta F, Colin L, Minic B, Goodman M. Comparison of vildagliptin and pioglitazone in patients with type 2 diabetes inadequately controlled with metformin. Diabetes Obes Metab. 2009;11(6):589-595.

196. Umpierrez G, Issa M, Vlajnic A. Glimepiride versus pioglitazone combination therapy in subjects with type 2 diabetes inadequately controlled on metformin monotherapy: results of a randomized clinical trial. Curr Med Res Opin. 2006;22(4):751-759.

197. Matthews DR, Charbonnel BH, Hanefeld M, Brunetti P, Schernthaner G. Long-term therapy with addition of pioglitazone to metformin compared with the addition of gliclazide to metformin in patients with type 2 diabetes: a randomized, comparative study. Diabetes Metab Res Rev. 2005;21(2):167-174.

198. Charbonnel B, Schernthaner G, Brunetti P, et al. Long-term efficacy and tolerability of add-on pioglitazone therapy to failing monotherapy compared with addition of gliclazide or metformin in patients with type 2 diabetes. Diabetologia. 2005;48(6):1093-1104.

199. Cefalu WT, Leiter LA, Yoon KH, et al. Efficacy and safety of canagliflozin versus glimepiride in patients with type 2 diabetes inadequately controlled with metformin (CANTATA-SU): 52 week results from a randomised, double-blind, phase 3 non-inferiority trial. Lancet. 2013;382(9896):941-950.

200. Lavalle-González FJ, Januszewicz A, Davidson J, et al. Efficacy and safety of canagliflozin compared with placebo and sitagliptin in patients with type 2 diabetes on background metformin monotherapy: a randomised trial. Diabetologia. 2013;56(12):2582-2592.

201. Schernthaner G, Gross JL, Rosenstock J, et al. Canagliflozin compared with sitagliptin for patients with type 2 diabetes who do not have adequate glycemic control with metformin plus sulfonylurea: a 52-week randomized trial. Diabetes Care. 2013;36(9):2508-2515.
202. Derosa G, Salvadeo SA, D'Angelo A, et al. Metabolic effect of repaglinide or acarbose when added to a double oral antidiabetic treatment with sulphonylureas and metformin: a double-blind, cross-over, clinical trial. Curr Med Res Opin. 2009;25(3):607-615.

203. Derosa G, Mereu R, D'Angelo A, et al. Effect of pioglitazone and acarbose on endothelial inflammation biomarkers during oral glucose tolerance test in diabetic patients treated with sulphonylureas and metformin. J Clin Pharm Ther. 2010;35(5):565-579.

204. Derosa G, Cicero AF, Franzetti IG, et al. A comparison between sitagliptin or glibenclamide in addition to metformin + pioglitazone on glycaemic control and beta-cell function: the triple oral therapy. Diabet Med. 2013;30(7):846-854.

205. Osonoi T, Saito M, Tamasawa A, Ishida H, Osonoi Y. Effects of sitagliptin or mitiglinide as an add-on to acarbose on daily blood glucose fluctuations measured by $72 \mathrm{~h}$ subcutaneous continuous glucose monitoring in Japanese patients with type 2 diabetes: a prospective randomized study. Expert Opin Pharmacother. 2014;15(10):1325-1335.

206. Arechavaleta R, Seck T, Chen Y, et al. Efficacy and safety of treatment with sitagliptin or glimepiride in patients with type 2 diabetes inadequately controlled on metformin monotherapy: a randomized, double-blind, non-inferiority trial. Diabetes Obes Metab. 2011;13(2):160-168.

207. Ceriello A, Johns D, Widel M, Eckland DJ, Gilmore KJ, Tan MH. Comparison of effect of pioglitazone with metformin or sulfonylurea (monotherapy and combination therapy) on postload glycemia and composite insulin sensitivity index during an oral glucose tolerance test in patients with type 2 diabetes. Diabetes Care. 2005;28(2):266-272.

208. Pfützner A, Schöndorf T, Tschöpe D, et al. PIOfix-study: effects of pioglitazone/metformin fixed combination in comparison with a combination of metformin with glimepiride on diabetic dyslipidemia. Diabetes Technol Ther. 2011;13(6):637-643.

209. Charbonnel B, Steinberg H, Eymard E, et al. Efficacy and safety over 26 weeks of an oral treatment strategy including sitagliptin compared with an injectable treatment strategy with liraglutide in patients with type 2 diabetes mellitus inadequately controlled on metformin: a randomised clinical trial. Diabetologia. 2013;56(7):1503-1511.
Clinical Interventions in Aging

\section{Publish your work in this journal}

Clinical Interventions in Aging is an international, peer-reviewed journal focusing on evidence-based reports on the value or lack thereof of treatments intended to prevent or delay the onset of maladaptive correlates of aging in human beings. This journal is indexed on PubMed Central, MedLine,

\section{Dovepress}

CAS, Scopus and the Elsevier Bibliographic databases. The manuscript management system is completely online and includes a very quick and fair peer-review system, which is all easy to use. Visit http://www.dovepress. com/testimonials.php to read real quotes from published authors. 